\title{
Trends in the timing of first marriage among men and women in the developing world
}

\author{
Barbara Mensch \\ Population Council \\ Susheela Singh \\ John B. Casterline
}

Follow this and additional works at: https://knowledgecommons.popcouncil.org/departments_sbsr-pgy

Part of the Demography, Population, and Ecology Commons, Family, Life Course, and Society Commons, International Public Health Commons, and the Maternal and Child Health Commons How does access to this work benefit you? Let us know!

\section{Recommended Citation}

Mensch, Barbara, Susheela Singh, and John B. Casterline. 2005. "Trends in the timing of first marriage among men and women in the developing world," Policy Research Division Working Paper no. 202. New York: Population Council. Version of record: https://doi.org/10.17226/11524 


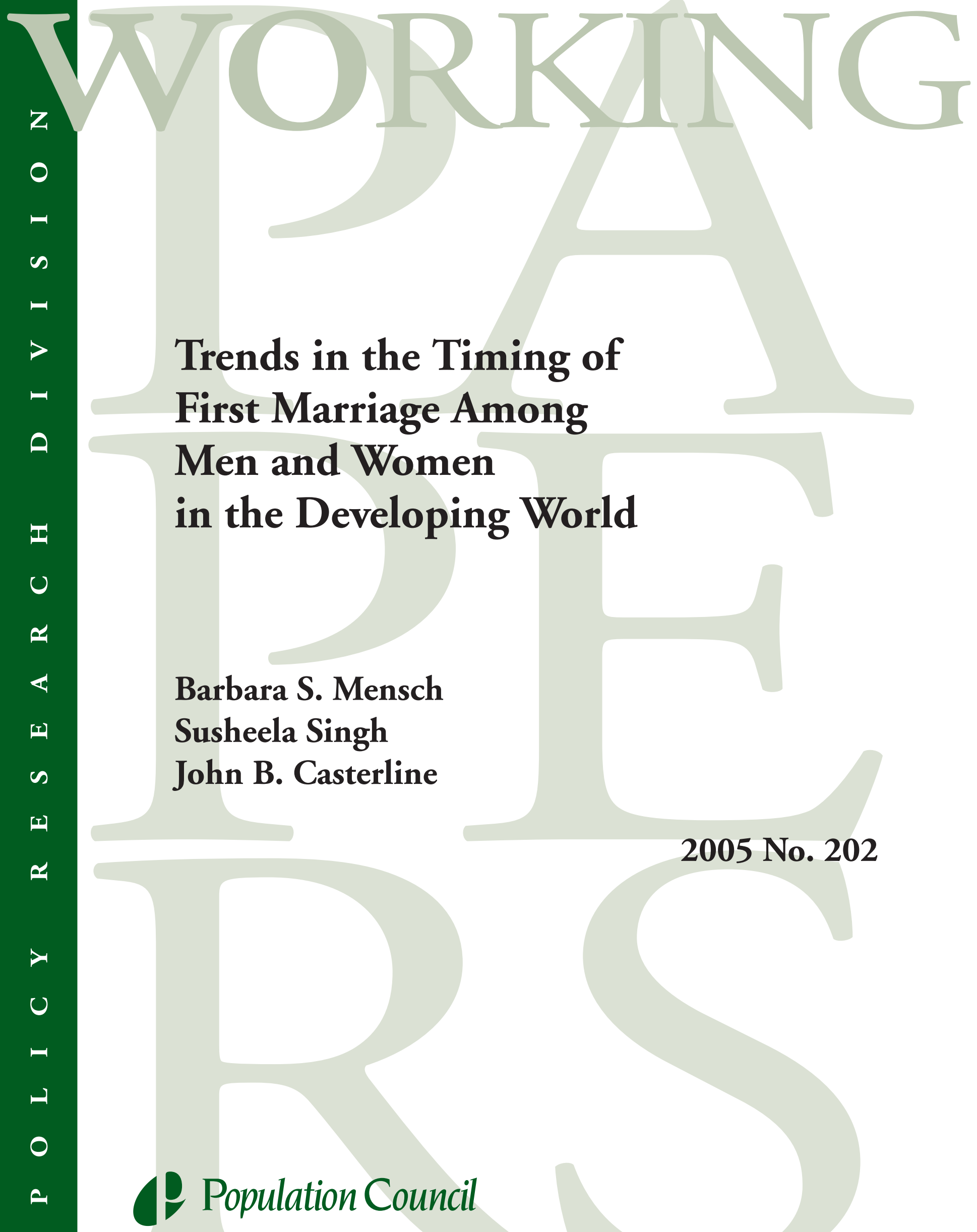




\section{(P) Population Council}

One Dag Hammarskjold Plaza

New York, New York 10017 USA

www.popcouncil.org

pubinfo@popcouncil.org

This material may not be reproduced without written permission from the authors. For a list of Policy Research Division Working Papers, including those that are currently available for downloading in PDF format, see www.popcouncil.org/publications/wp/prd/rdwplist.html.

ISSN: $1554-8538$

(C) 2005 The Population Council, Inc. 


\section{Trends in the Timing of First Marriage Among Men and Women in the Developing World}

Barbara S. Mensch, Susheela Singh, and John B. Casterline

Barbara S. Mensch is Senior Associate, Policy Research Division, Population Council. Susheela Singh is Vice President for Research, The Alan Guttmacher Institute. John B. Casterline is Professor of Sociology and Demography, Population Research Institute, Penn State University.

Acknowledgments: The authors are grateful to Monica Grant for much of the analysis for this paper; Shelley Clark for her insightful critique of the section on age at marriage and HIV risk; John Bongaarts for his analysis comparing singulate mean age at marriage with median age at marriage; and the NAS Panel on Transitions to Adulthood in Developing Countries, especially Nan Astone, Jere R. Behrman, and Cynthia B. Lloyd, for useful comments. Funding for this study was provided by the U.K. Department for International Development, The William and Flora Hewlett Foundation, and The Andrew W. Mellon Foundation..

An earlier version of this paper was presented at the annual meeting of the Population Association of America, Minneapolis, May 2003, and will also be published as chapter 5 in the forthcoming National Academies Press volume, The Changing Transitions to Adulthood in Developing Countries: Selected Studies, edited by Cynthia B. Lloyd, Jere R. Behrman, Nelly P. Stromquist, and Barney Cohen. 


\begin{abstract}
The timing of first union merits investigation not only because of the close temporal link between marriage and the onset of childbearing, but also because the age when men and women marry has implications for the organization of family life and for gender relations within society. This paper begins by reviewing the contributions of various social science disciplines to an understanding of the timing of marriage. Using current status data from 73 countries provided by the United Nations Population Division and retrospective data from 52 Demographic and Health Surveys conducted between 1990 and 2001, we then examine recent trends in the timing of first marriage or union for men and women in the developing world. With the exception of South America for both sexes and South and Southeast Asia for men, substantial declines have occurred in the proportion of young men and women who are married. Given the differentials in the timing of marriage by educational attainment and residence, we assess whether the decline in the proportion of young people who are married is related to increases in schooling and urbanization. Expansion of schooling for women has had some impact, but a considerable portion of the reduction in early marriage is not explained by changes in levels of education. We consider other factors that might account for the increase in age at marriage. Finally, we review what is known about the consequences of changing age at marriage with a particular focus on risk of HIV infection.
\end{abstract}


For many demographers age at first union is worthy of attention because of the close temporal link between marriage and the onset of childbearing. Thus, a number of studies over the years have documented the contribution of changes in the timing of marriage to fertility transitions, both historically in developed countries and currently in developing countries (e.g., Coale and Treadway, 1986; Casterline, 1994; Rosero-Bixby, 1996). Some scholars have argued, however, that "weaknesses in the field of nuptiality research stem from its heavy focus on the fertility implications of nuptiality patterns" (Smith, 1983, p. 510). In charging his fellow demographers to think more broadly about the subject of marriage, van de Walle (1993, p. 118) asserts that we should care about marriage patterns "in their own right" because understanding "nuptiality change could further the understanding of other social change." Indeed, for those interested in family formation, the timing of first union merits investigation not only because it signals the initiation of reproductive life but also because the marriage process reflects the way family life is organized and functions in a particular culture and because when, whom, and how one marries all have implications for gender relations within society (Malhotra, 1997).

The age when men and women form marital unions is influenced by social norms and expectations regarding their roles as spouses and parents-factors that are plausibly changing with globalization, urbanization, and rising educational attainment; as such, the timing of marriage should be of considerable relevance to researchers interested in the transition to adulthood in the developing world. If, for example, men are now postponing marriage because of greater expectations about job status and employment stability and the material possessions needed to form a household, and women are delaying marriage because of shifting gender roles, it is important to document these patterns of behavior and to understand their potential implications both for individuals and for the larger society.

In recent years, few demographers have heeded van de Walle's appeal to explore the process and timing of marriage for its own sake. Yabiku and colleagues' (Yabiku, 2003; Yabiku et al., 2002) analysis of the effect of community variables on the timing of marriage in a region of Nepal experiencing rapid social change is a notable exception. ${ }^{1}$ There is, however, a large descriptive literature. Although lacking much in the way of explanatory variables, this research documents trends and differentials in the age of first union among women, with a particular focus on the practice of early marriage in the developing world (see, e.g., Jejeebhoy, 1995; Singh and Samara, 1996; Choe et al., 2001; Heaton et al., 2002; Rashad and Osman, 2003; Westoff, 2003).

This interest in early marriage reflects the concern of human rights and reproductive health advocates who, in putting "child marriage" on the international agenda, have emphasized the potentially harmful consequences for young women of marrying too early. Researchers at the International Center for Research on Women (2004) highlight these possible problems in dramatic fashion:

Child brides are robbed of the ordinary life experiences other young people take for granted. Many are forced to drop out of school. Their health is at risk because of early sexual activity and childbearing. They 
cannot take advantage of economic opportunities. Friendships with peers are often restricted. Child marriage deprives girls of basic rights and subjects them to undue disadvantage - and sometimes violence. Countries with a high percentage of child marriage are more likely to experience extreme and persistent poverty, and high levels of maternal and child mortality.

Although a focus on marriage before age 18 - the internationally established age of adulthood-has gained prominence, research has yet to establish the causal links between early marriage and poor outcomes among women. Is early marriage in and of itself the problem or is it the characteristics of those who marry early?

In contrast to the extensive documentation of female age at marriage, the literature on men is sparse (Malhotra, 1997). This limited attention to men is partly attributable to the restriction of demographic surveys, until the past decade or so, to female respondents. It is also due to the infrequency, across a wide spectrum of countries and cultures, of men marrying during their teenage years, and it is early marriage that is considered problematic and thus worthy of consideration.

In this paper we examine trends in the timing of first marriage or union for men and women. We define marriage broadly to include all socially recognized unions, including legal marriage and any other type of union that is recognized and reported in particular countries. The principal focus is on documenting trends in age at marriage for the major regions of the developing world. We also examine the current extent of early marriage, differences between men and women in trends in age at marriage, the association between age at marriage and sociodemographic characteristics, specifically education and rural-urban residence, and age at marriage and risk for HIV infection. To the extent that changing patterns of behavior are revealed, we try to identify the sources of such transformations and draw on the demographic literature to provide insights.

\section{Understanding THE TIMING OF MARRIAGE}

A number of scholars have conducted research on the timing of marriage. We begin with a brief review of the contributions of various social science disciplines to an understanding of age at marriage.

\section{Historical demography}

Although historical demographers have done an admirable job of documenting marriage patterns throughout Europe over the past few hundred years, they have fared less well in identifying particular factors that explain trends across cultures. Hajnal (1965) first observed what he called a "European" pattern: late age at marriage and high proportions of people remaining unmarried. In describing this distinctive pattern that prevailed from at least the eighteenth century, he hypothesized that an association existed between marriage and household formation, arguing that when marriage involved the establishment of a new household, as it did in much of Western and Northern Europe, the acquisition of resources and skills was a determining factor in the decision to wed. 
Wrigley and colleagues (1997, p. 122), in their history of English population from the end of the sixteenth century to the beginning of the nineteenth, supported this view, concluding not only that "the pattern that Hajnal identified was of long standing in England" but also that the decision to marry hinged on the ability to set up an independent household.

Although many have noted its "tremendous influence in the historical study of European marriage" (Ehmer, 2002, p. 306), Hajnal's theory of the links between age at marriage and economic self-sufficiency is not without its critics. Watkins (1986, p. 325), in her investigation of marriage in Europe between 1870 and 1960, reveals the inadequacy of Hajnal's explanation, at least in understanding change at the level of geographic aggregates. Examination of provincial data from the late nineteenth century reveals that nuptiality patterns were similar in neighboring provinces, but not necessarily within regions of a particular country. She argues that these contiguous regions shared a common culture and language and not necessarily common occupational structures, suggesting that societal conventions with regard to the timing of marriage existed independent of particular economic conditions. Other studies also suggest that the decision about when to marry may be rooted as much in societal norms as in economic realities. Examining the experience in cities in Northwest Europe, Lynch (1991) observed that the pattern of late age at marriage and high rates of celibacy that characterized village society also described more urbanized areas in the nineteenth century. Although Lynch presents herself as an adherent of Hajnal's thesis, her argument that the European marriage pattern prevailed even as Malthusian constraints weakened with the rise of fertility control is not consistent with a theory that connects age at marriage to economic resources. She claims that late age at marriage represents a set of cultural values, albeit values that emanated, in part, from the economic realities of times past.

Studies of individual countries also reveal the inadequacy of an explanation linking household structure, the economic environment, and age at marriage. For example, an analysis by Kertzer and Hogan (1991) of data from an agricultural region of north-central Italy in the late nineteenth and early twentieth centuries revealed that women married late, on average at around 24 to 25 years, even though multiple-family households were common and patrilocal residence was the norm. Moreover, these authors observed that marriage age in this region did not decline throughout "a period of dramatic social and economic changes," when wage labor supplanted sharecropping (p. 34). In Ireland, even as incomes began to rise in the late nineteenth century, celibacy and late age at marriage continued to prevail (Guinnane, 1991). Proto-industrialization, which provided wage-earning opportunities for young men and women, did not always lead to reduced age at marriage, as Gutmann and LeBoutte (1984) demonstrate for eastern Belgium. They argue that land-ownership patterns, the speed with which industrial development took place, and the nature of that industry all played a role in the timing of marriage. Furthermore, case studies from other areas in Europe do not show a strong association between occupational groups and age at marriage (Kertzer and Hogan, 1991).

These demographic studies of historical Europe are useful for scholars investigating marriage in the developing world if only because they demonstrate how 
nuptiality trends defy easy explanation. Although age at marriage is likely to be sensitive to the economic environment, particular marriage patterns also appear to be shaped by the distinctiveness of individual family systems. ${ }^{2}$

\section{Social anthropology}

For social anthropologists, kinship systems - which include marriage rules and residential arrangements - have traditionally been a focal, if not the focal point of ethnographic inquiry. Although much effort has gone into documenting spouse-selection patterns, living arrangements after marriage, and inheritance systems, the subject of age at marriage has been incidental to the larger goal of describing the way in which the kinship system and marriage rules function to maintain social order.

The structural-functionalist approach to kinship dominated cultural anthropology throughout much of the twentieth century. Although this paradigm is now considered overly "static" and even "obsolete" (Das Gupta, 1997, p. 36), many anthropologists are still interested in kinship patterns. The focus is no longer on delineating complicated marriage rules, however. Rather, kinship is explored within its broader political and economic context with a view toward understanding social change. Ahearn's (2001) ethnographic study of the way in which increased literacy and exposure to Hindi soap operas have led to a shift from arranged and capture marriages toward love marriages in a Nepalese village is an example of this new type of kinship research. Yet she pays no attention to whether this transformation in the marriage process has had an effect on the timing of marriage. As was true of earlier kinship studies, Ahearn provides no discussion of age at marriage.

A collaborative study between anthropologists and demographers, also conducted in a Nepalese village, focuses explicitly on age at marriage. In the introduction to their chapter, Dahal and colleagues (1993, p. 305) explain why anthropologists should not ignore the timing of marriage:

If particular marriage forms are evidence of wider strategies of social reproduction ... then the timing of marriage should itself be seen as a part of that process. Thus marriage timing is no less the proper study of anthropology than any other element of marriage behavior. At the same time, marriage timing should be seen to have implications beyond the merely demographic.

Dahal and colleagues are critical of even the "most anthropologically informed demographers" who ignore family context in explaining age at marriage and include only individual factors, such as education, to elucidate behavior change. Indeed, the explanatory variables used in this examination of Nepal set the research apart from conventional survey analyses. In addition to asking the standard demographic questions, the authors collected information on marriage characteristics of the parental generation, including measures of kin status of parents (cross-cousin or not), the nature of material exchange at their marriage, and the relative landholding of their families. They also 
gathered data on mothers' characteristics, including the inheritance at marriage and whether Nepali is spoken as well as the local language, all measures that reflect social status. Family context-namely, "access to kin and marriage partner networks, intergenerational control and the prestige of natal groups"-is found to be significant in explaining marriage timing (Dahal et al., 1993, p. 319).

\section{Sociology}

Family sociologists, in contrast to social anthropologists, have not generally considered marriage patterns in developing countries to be within their purview. Goode's classic volume, World Revolution and Family Patterns (1963), one of the standard textbooks of modernization theory, is the exception. Goode emphasizes the "fit" between the conjugal family and modern industrial society, with its need for a geographically and socially mobile population. According to Goode, the ideal type of conjugal family excludes relatives from everyday decisionmaking, establishes a new household at the time of marriage, and, because the young person selects his or her own partner, is based on mutual attraction between spouses rather than on an alliance between families. ${ }^{3}$ Goode (p. 8) notes that in the West, the age at marriage for both men and women dropped during the twentieth century, leading him to conclude that predicting trends in age at marriage as a consequence of other secular changes in society is problematic:

When such a [conjugal] system begins to emerge in a society, the age at marriage is likely to change because the goals of marriage change, but whether it will rise or fall cannot be predicted from the characteristics mentioned so far. In a conjugal system, the youngsters must now be old enough to take care of themselves, i.e., they must be as old as the economic system forces them to be in order to be independent at marriage.

Goode does not argue that industrialization and urbanization "caused" a change in family patterns in the West. Rather, he observes that the family has had an independent effect on the development of industrialization. He claims that "no one has yet succeeded in stating the determinate relations between family systems and economic or technological systems" (p. 22).

Although Goode was writing more than 40 years ago, we argue that success still eludes us. With the exception of work by Lesthaeghe and his colleagues (1989) on subSaharan Africa, and research by Fricke (Fricke et al., 1986), Malhotra (Malhotra, 1991, 1997), Malhotra and Tsui (1996), and Yabiku (Yabiku et al., 2002; Yabiku, 2003) on

South Asia, few demographic studies explore the timing and process of marriage in developing countries in any depth. In part this is a consequence of the limited breadth of the typical demographic survey. In contrast, the Asian Marriage Surveys, which were used by Malhotra and by Fricke and his colleagues, collected extensive data on the marriage process. These surveys are of limited utility for the analysis of the timing of marriage, however, because they are restricted to those who are already married. 


\section{Economics}

Economists have been less concerned than other social scientists with explaining marital behavior in the developing world. To the extent that they have been interested in marriage, their focus has been on modeling assortative mating (Montgomery and Sulak, 1989) and on the increase in dowry payments in South Asia (Rao, 1993a and 1993b; Anderson, 2003). Gary Becker's (1973) seminal article on the theory of marriage is one of the few works by an economist that address the issue of age at marriage. According to Becker, marriage is a manifestation of utility-maximizing behavior: people wed when the utility of being married exceeds that of being single. At the core of his argument is the notion that men and women bring different attributes to marriage and have different roles, such that there is "positive assortative mating of complementary traits" (Boulier and Rosenzweig, 1984, p. 714). As the wage differential between men and women narrows, and presumably as women and men achieve greater economic and social equality, women's incentive to marry decreases. Since the publication of Becker's theory, few economists have produced empirical analyses of marriage in the developing world. Using data from the early 1970s in the Philippines, Boulier and Rosenzweig (1984) provide confirmation of Becker's theory of marriage. They demonstrate that although the effect of education on age at marriage is exaggerated in models that treat education as exogenous, additional schooling leads women to marry later. Brien and Lillard (1994) show that when one controls for the effect of delayed marriage on education- that is, for the potential endogeneity of education - later age at marriage among women in Malaysia is explained in large part by increased enrollment and attainment. As Becker would predict, with increased schooling the opportunity cost of marriage rises for women.

With the exception of Becker's work, we have few theories that explicitly address age at marriage, even fewer studies that economists would consider acceptable in addressing the endogeneity problems that arise in studies of the determinants of marriage timing, and still fewer that collect the appropriate data to explain adequately when people marry. Nevertheless, a considerable literature on the correlates of age at marriage exists, as does speculation about determinants and trends, particularly about reasons for the increase in age at marriage among women. In the next section, we analyze data on age at marriage from 83 developing countries. We then return to the demographic literature to help us shed light on the trends we observe.

\section{DATA SOURCES}

Data on the age at first marriage are obtained from two sources: (1) a database compiled by the United Nations Department of Economic and Social Affairs, Population Division, drawn in part from population censuses, and (2) nationally representative Demographic and Health Surveys (DHS).

The UN database presents the proportion of the population that is married in fiveyear age groups for most developing countries (United Nations Department of Economic

and Social Affairs, Population Division, 2000). For this analysis, we consider all 
countries in Africa, Asia, and Latin America with the exception of those identified by the World Bank as "high income" and those with a population of less than 140,000 (World Bank, 2002). ${ }^{4}$ Given our focus on trends in marriage age, we have identified 73 countries of the 117 that meet our criteria for which recent data - that is, data collected in 1990 or later-are available and for which information exists from two censuses or surveys at least ten years apart. ${ }^{5}$ For analyses drawing upon this database, we excluded countries for which a census or survey was not available for both sexes. Moreover, we used the same data set for both men and women even if a more recent census or survey was available for women, because we wanted to have fully comparable data for both sexes. There are 1.4 billion young people aged 10-24 in these 117 countries; 87 percent or 1.2 billion are resident in the 73 countries for which data on trends in proportions married are available. Coverage varies considerably by region.

These data represent approximately 90 percent or more of the population in East and Southern Africa, South Central and Southeast Asia, East Asia, South America and the Caribbean, and Central America, but only 63 percent of the population in the Middle East, 31 percent in West and Middle Africa, and 38 percent in the former Soviet Asia. Results for the subregion of East Asia consist entirely of China, as data are unavailable for the two other countries: Mongolia and North Korea. Populous countries for which data are unavailable from the UN database include Afghanistan, Algeria, Democratic Republic of the Congo, Ghana, Iraq, Nigeria, Saudi Arabia, Uzbekistan, and Vietnam.

Survey data are drawn from the DHS conducted by Macro International from 1990 to $2001 .^{6}$ Data on age at marriage are obtained from personal interviews with respondents of reproductive age and are part of an extensive questionnaire covering sexual and reproductive behavior. Surveys of women (typically aged 15-49) were available for 51 countries in South and Southeast Asia, North Africa and the Middle East, sub-Saharan Africa, and Latin America and the Caribbean. Surveys of men (aged 15-59, in most cases) were available for 32 countries, 29 of them in sub-Saharan Africa, Latin America, and the Caribbean. ${ }^{7}$ Unmarried women were not included in the survey of individual women for a number of surveys in Asia and the Middle East. However, unmarried women are listed in the household survey, and information on their age, education, and rural-urban location is obtained for these countries, with some exceptions noted in the relevant tables. Using weights provided as part of the microdata files, we adjust for the missing unmarried women by age, place of residence, and education, so that the denominators for the proportion married correctly include all women in the respective subgroups.

The country-specific data are aggregated into averages for subregions (using United Nations geographic groupings). ${ }^{8}$ For both sets of data, weighted averages are calculated, where the weights are the country's percentage of the region's population or income grouping's population aged 10-24 based on UN estimates for $2000 .{ }^{9}$

For a few countries, DHS data are available but UN data are not. For example, although a DHS exists for Nigeria-the most populous country in sub-Saharan Africathe UN does not provide data for both men and women for the two time periods required. Appendix Table A-1 lists the individual countries from each source by region. 
Census data, which are the main source for the database compiled by the United Nations Department of Economic and Social Affairs, Population Division, are generally reported by the head of household, not by individual household members. By comparison, the DHS data on marital status and age at marriage are obtained from personal interviews with the individual respondents, with the exception of unmarried women in some Asian and Middle Eastern countries.

As noted above, we apply the broad definition of marriage generally used by cross-country comparative studies to include all forms of socially recognized unions: cohabitation, consensual unions, "free unions," and marriage legitimated by custom, religious rites, or civil law. The definition of marriage used in censuses, however, may be more variable than that used in standardized surveys. For the DHS, marriage is a selfdefined state. Respondents are coded as married if they say so in response to questions on whether they are currently or were ever married or are living with a man. Thus, age at first marriage is typically age at first cohabitation with a partner or husband (Kishor, 2003). For censuses, countries typically define marriage to reflect the forms of marriage and union that are generally recognized and accepted, and they obtain such information accordingly. As a result, for the most part data on marriage or union status are largely comparable between censuses and surveys. For example, in Latin America census questions on marital or union status include the category "consensual union" because this is a widely occurring and acknowledged form of union in this region. However, in countries where cohabitation is much less common, "consensual union" may not be explicitly included as a category, with the result that this type of arrangement may be underreported.

For the purposes of this analysis, we assume that the reporting of age and marital status in the censuses and surveys is accurate. In certain populations, however, this assumption may be questionable, particularly when the reporting is retrospective. In Africa, where formation of a marital union has been described as a process that takes place in stages, marriage is not a well-defined event, and therefore age at marriage is difficult to establish (van de Walle and Meekers, 1994). To the extent that particular rites and ceremonies have lost significance or been eliminated as the population becomes more urbanized and better educated, comparisons over time are problematic. In countries where, at least officially, early marriage violates newly passed legislation, observed declines in the proportion married at or by a particular age may simply reflect increases in deliberate misreporting. Finally, in countries where age is not accurately reported, the timing of an event that occurred in the remote past is often estimated to have taken place closer to the survey than it did. Thus, in the DHS older women are more likely to report that a marriage took place at a later age than it may have (Blanc and Rutenberg, 1990).

\section{Trends in Age at MARriage}

To what extent has age at marriage changed in recent years? Have the trends for men and women mirrored one another or are they divergent? If men and women are now postponing marriage in increasing numbers, to what can such a transformation in marriage patterns be attributed? 
In this section, we analyze two different measures of age at marriage to describe trends: (1) the proportion of specific age groups married, which is based on reports of current status, and (2) the proportion of women and men married by specific ages, which is based on retrospective reports. ${ }^{10}$ We include these measures because they are commonly used and we want to determine whether they present a consistent picture of trends in age at marriage in the developing world. Some differences exist in the extent of geographic coverage of the two measures. The first measure, taken from the UN database, includes 73 countries with information for each of the time periods of interest (1970-1989 and 1990-2000) for men and women, and has some representation from all developing regions. The second measure, the proportion married by specific ages, is based for women on 51 DHS countries with representation from seven of the eight developing regions and is based for men on 29 DHS countries with representation from only the Caribbean, Latin America, and sub-Saharan Africa.

The United Nations Population Division monitors marriage trends using the singulate mean age at marriage (SMAM), a synthetic cohort measure calculated from census or survey data on the proportions who are single by five-year age groups (United Nations, 2004). Although this measure is referred to as the mean age at marriage, it is actually the mean age at first marriage among those who marry by age 50, or more precisely the average number of years spent single for those who marry before age 50 (United Nations Department of International Economic and Social Affairs, 1990). ${ }^{11}$ Because the SMAM assumes stability (no change over time in the age-specific incidence of first marriage), it can be misleading when an increasing fraction of young people delay marriage and ultimately remain unmarried. If the proportion of young people who ultimately marry is lower than the current proportion aged 50 who have married, the SMAM will be artificially inflated. Preston and colleagues (2001, p. 89) caution against using the SMAM when nuptiality patterns are changing, noting that the "SMAM is a hodge-podge of rates in the recent and distant past." However, they do not indicate how and to what extent it is distorted. A comparison of the median age at marriage with the singulate mean age at marriage for women in 118 DHS surveys reveals that for 117 of the 118 the SMAM is higher than the median by about seven years on average. This difference is to be expected given that the distribution of marriage ages is right skewed (analysis conducted by Bongaarts for this paper, not shown). ${ }^{12}$

\section{Trends in the proportion married among young people aged 15-29}

Tables 1 and 2 provide current status data by region on the proportion of women married for three age cohorts, 15-19, 20-24, and 25-29, and the proportion of men (for whom marriage during the teenage years is rare) for two age cohorts, 20-24 and 25-29. Given that the interval between censuses or surveys varies by country, an annualized rate of change is computed.

For all regions except the former Soviet Asia and South America, where early marriage was not common even 10 to 20 years ago, teenage marriage has declined considerably among women. The reduction is particularly striking in Africa. The proportion married among women aged 20-24 has also fallen markedly in most regions, 
again with the exception of South America. Although the majority of women in developing countries are married by ages 25-29, regions where 15 to 25 percent of women are still not married by their late 20s include South America, the Caribbean and Central America, the Middle East, the former Soviet Asia, and East and Southern Africa.

As noted above, among men marriage during the teenage years is extremely rare. Marriage in the early 20s is also much less common among men than among women and in some regions has declined substantially in recent years. For example, in East and Southern Africa, East Asia, the former Soviet Asia, and the Middle East, a large reduction has taken place in the proportion of men married at ages 20-24 in the past decade or so.

By ages 25-29, sizable numbers of men in developing countries have married. However, in certain regions, marriage is postponed until the 30 s for a large proportion of men. In South America, this pattern is observed in the earlier time period and seems to have stabilized. Recently, in the Middle East and the former Soviet Asia, we see evidence of increasing delay.

In summary, Tables 1 and 2 reveal declines in the proportion married for both sexes in most regions; the exceptions are South America for men and women, and, for men only, West and Middle Africa and South and Southeast Asia. For six of the eight regional groupings, the patterns for men parallel those for women; the exceptions are South and Southeast Asia and West and Middle Africa, where substantial declines are observed in the proportions married for women at ages 15-19 and 20-24, but little or no change for men at ages 20-24 and 25-29. Although many regions have witnessed declines in the proportions married among young people of both sexes, it is in China and the countries of the Middle East that the change has been most consistent across the three age groups for women and the two age groups for men.

\section{Trends in the proportion of women married by ages 18, 20, and 25}

The Demographic and Health Surveys provide additional information to supplement what is available from the United Nations database. Age at first marriage, rather than just current marital status, is obtained by these surveys, enabling the calculation of the proportion of women married by a particular age rather than just the percentage of a particular age group who are married. The one drawback of the surveys is that they have been conducted in fewer countries than are included in the UN database. Moreover, the analyses are based on retrospective reporting, which may be subject to recall error. To reflect the earlier timing of marriage among women, we examine the proportions married before ages 18,20, and 25, and for men the proportion married before ages 20,25 , and 30 . We compare these proportions across age groups in order to approximate trends over time.

The data for the proportion of women married by a particular age are provided in Table 3. The first column indicates the percentage of each region's population that is represented by the DHS. Coverage is highest in East and Southern Africa, with approximately 92 percent of the population represented. Coverage is lowest in the Caribbean and Central America where, because no recent survey is available for Mexico 
(by far the largest country), only about 20 percent of the population is represented. No data are available for East Asia, which includes China. Note, however, that a few countries for which DHS data are available are not included in the UN database: Armenia, Ghana, Guinea, Madagascar, Nigeria, Togo, Uzbekistan, Vietnam, and Yemen.

The trends in early marriage revealed by data in Table 3 are more or less consistent with those shown in Table 1, which is reassuring given the difference in the number of countries and the nature of the data-retrospective versus current status. First, the regional rankings essentially follow the same sequence. Furthermore, the ranking changes little by age group. West and Middle Africa is the region with the greatest proportion of women marrying at young ages, followed by South and Southeast Asia, East and Southern Africa, and the Caribbean and Central America. The Middle East, South America, and the former Soviet Asia have smaller proportions of women who marry early. Second, a comparison of the proportion married across age groups indicates little movement toward later marriage in South America, the Caribbean and Central America, and the former Soviet Asia. Indeed, in the former Soviet Asia, a greater proportion of women aged 20-24 have married early than have women aged 30-34. Other regions reveal a considerable decrease in early marriage, with a greater decline in the proportion married by age 18 than by age 20 . The decline in early marriage among women is particularly sizable in the Middle East, where a 49 percent reduction is seen between 20-24-year-olds and 40-44-year-olds in the proportion married by age 18, and a 38 percent decline is seen in the proportion married by age 20 . Little change is observed in the proportion of women married by age 25 among the two age groups for which these changes can be computed, with the exception of the Middle East and sub-Saharan Africa. Note also that, with the exception of the former Soviet Asia, the regional ranking for marriage by age 25 among 30-34-year-olds is similar to that for marriage by age 18 . For example, West and Middle Africa and South and Southeast Asia are the regions with the highest proportion of women married by ages 18 and 25 .

To summarize the data on trends in age at marriage among women, although marriage during the teenage years is declining in many regions of the world, substantial proportions of women are still marrying extremely early. Indeed, as Table 3 indicates, for the countries where DHS data are available, more than a third of women currently aged 20-24 married before age 18 .

\section{Trends in the proportion of men married by ages 20, 25, and 30}

Recently, Demographic and Health Surveys have been conducted among men in a number of countries in sub-Saharan Africa, Latin America and the Caribbean, and the former Soviet Asia. However, only in sub-Saharan Africa and Latin America and the Caribbean were male surveys conducted in a sufficient number of countries to aggregate the data and generate regional averages. Table 4 provides data on the proportion of men married by ages 20,25 , and 30, by age group at time of the survey, for 29 countries with surveys between 1994 and 2001: nine East and Southern African countries, 14 West and Middle African countries, three South American countries, and three Caribbean and Central American countries. 
Although this table indicates little consistent change in Latin America and the Caribbean, slight declines in the proportion of men married in both sub-Saharan African regions are observed. However, the declines are considerably smaller than those seen for women. Compared to the findings on men's age at marriage in Table 2, a smaller decline is observed for East and Southern Africa and a larger decline for West and Middle Africa. These discrepancies arise because of differences in the countries included in the analyses. Nigeria, which constitutes nearly half of the population of West Africa and where there has been a considerable decline in early marriage for young men (10.8 percent married by age 20 among 20-24-year-olds, compared with 19.5 percent among 40-44-year-olds), is not included in the UN database. Furthermore, DHS data are not available for South Africa, where a large decline has occurred in the proportion of men married in their $20 \mathrm{~s}$. Because a substantial percentage of the male population is not included in our DHS analysis, the regional estimates may be distorted. Indeed, Westoff $(2003$, p. 1$)$, in a recent analysis of DHS data on marriage, observes that "the trend toward later ages at marriage for women is not evident for men surveyed in sub-Saharan Africa," an assertion that would likely be modified if data were available for more countries.

\section{Differentials in Age at Marriage}

An examination of differentials in the timing of marriage by educational attainment and place of residence, which is possible with DHS data, may provide insights into the forces behind the trends we have observed. Tables 5 and 6 are limited to women aged 20-24 and indicate the proportion married by age 18 by years of schooling attained and by rural-urban residence, respectively. Table 7 is limited to men aged 20-24 in subSaharan Africa, Latin America, and the Caribbean, and indicates the proportion married by age 20 by years of schooling attained and rural-urban residence.

As expected, large differentials by education and residence are observed for both sexes. Women and men with eight or more years of schooling are much less likely to marry early than are those with zero to three years of schooling. Young people in urban areas are much less likely to marry early than are those living in the countryside. Although these differentials are considerable, in the regions where data are available for both men and women, greater variability exists in the timing of marriage by education than by residence. For example, in East and Southern Africa, more than four times more women with zero to three years of schooling marry before age 18 than do women with eight-plus years of schooling, whereas 1.6 times more women in rural areas marry before age 18 than do women in urban areas.

\section{Explaining Trends in Age at MARriage}

As we have documented, in most regions of the developing world young people are marrying later than their counterparts in previous generations. In light of how widespread this change is, an explanation that spans different cultures seems warranted. Yet, we recognize the specificity of marriage markets and the marital process across time and place. For example, in West Africa, changes in the practice of polygyny, a distinctive feature of that region, may help to explain why age at marriage is increasing for women 
but not for men in several countries. ${ }^{13}$ While acknowledging the unique characteristics of nuptiality in individual countries, we seek some general explanations as to why early marriage is less common now than in the past.

\section{Explaining trends among women}

The rise in educational attainment. Increased schooling is thought to be a likely explanation for the increase in age at first marriage among women. In all regions of the developing world, save for the countries of the former Soviet Asia, an increase has occurred in the past few decades in mean grades of schooling attained by young women (Lloyd, 2005). This expansion in education, combined with the magnitude in the differentials we observe in Table 5 in all regions, has led many to argue that increased schooling is the main force underlying the delay in first marriage among women (United Nations Commission on Population and Development, 2002).

A closer examination of the data raises doubts about the dominant role of increased education as a cause of nuptiality change. For one thing, trends in education and age at marriage are not always closely connected. Indeed, the region with the largest increase in educational attainment among young people - South and Southeast Asia-is not the region with the largest decline in early marriage. (Early marriage among young women has fallen most dramatically in the Middle East.) Moreover, although years of schooling have increased in Latin America in the past few decades, almost no change has occurred in age at marriage. Figure 1 plots the association for 49 DHS countries between the absolute intercohort change (the two age cohorts are 20-24 and 40-44) in the proportion of women marrying before age 18 and intercohort change in mean grades of schooling. ${ }^{14}$ Although an association between changes in schooling and marriage is evident - after all, most developing countries have experienced both a rise in educational attainment and a rise in age of marriage-Figure 1 reveals a weaker association than might be expected, given the determining power often attributed to educational change.

An alternative approach to this question is to take as a starting point the observed individual-level relationship between marriage and educational attainment and to consider, given this relationship, how much intercohort change in early marriage might be expected to follow from the intercohort change in educational attainment. The individual-level relationship can be obtained by estimating regressions of marriage prior to age 18 on years of schooling. This effect (i.e., the regression coefficients) can then be applied to the observed intercohort change in years of schooling to calculate an "expected change" in the probability of early marriage that would be generated by schooling change. The methodology can be briefly described as follows: The observed proportions marrying prior to age 18 can be designated $\mathrm{O}_{1}$ and $\mathrm{O}_{2}$, for the older and younger cohorts, respectively, and the observed change in the proportion marrying young is:

$$
\Delta \mathrm{O}=\mathrm{O}_{1}-\mathrm{O}_{2} .
$$

To obtain the "expected change" due to changes in schooling, two regressions are estimated, one for each cohort: 


$$
\begin{aligned}
& \mathrm{p}\left(\mathrm{M}_{18}\right)_{1}=\mathrm{a}_{1}+\mathrm{b}_{1} \mathrm{~S}_{1} \\
& \mathrm{p}\left(\mathrm{M}_{18}\right)_{2}=\mathrm{a}_{2}+\mathrm{b}_{2} \mathrm{~S}_{2},
\end{aligned}
$$

where $p\left(M_{18}\right)$ is the probability of marrying prior to age $18 ; S$ is the educational attainment (schooling) of each woman; $a$ and $b$ are estimated parameters; and 1 and 2 are subscripts referring to the older (1) and younger (2) cohorts.

An "expected" proportion marrying before age 18 for the younger cohort is calculated as:

$$
\mathrm{E}_{2}=\operatorname{mean}\left(\mathrm{a}_{1}+\mathrm{b}_{1} \mathrm{~S}_{2}\right)
$$

This represents the predicted proportion marrying early in the younger cohort given the educational attainment of these women and the association between educational attainment and early marriage observed in the older cohort. That is, this is a hypothetical of the following sort: Suppose the association between schooling and early marriage observed in the older cohort persisted in the younger cohort, along with the increase in educational attainment; if so, what proportion of the younger cohort would be expected to marry young? From this an expected change can be calculated:

$$
\Delta \mathrm{E}^{*}=\mathrm{E}_{2}-\mathrm{O}_{1}
$$

An equally valid hypothetical can be calculated by reversing the cohorts:

$$
\mathrm{E}_{1}=\operatorname{mean}\left(\mathrm{a}_{2}+\mathrm{b}_{2} \mathrm{~S}_{1}\right)
$$

This represents the predicted proportion marrying early in the older cohort given the educational attainment of these women and the association between educational attainment and early marriage observed in the younger cohort. From this an alternative expected change can be calculated:

$$
\Delta \mathrm{E}^{+}=\mathrm{E}_{1}-\mathrm{O}_{2}
$$

Both $\Delta E^{*}$ and $\Delta E^{+}$are defensible assessments of the amount of change in early marriage expected due to changes in schooling. Therefore, we simply average the two:

$$
\Delta \mathrm{E}=\left(\Delta \mathrm{E}^{*}+\Delta \mathrm{E}^{+}\right) / 2 .
$$

$\Delta E$ is the "expected change" in the proportion marrying young in the following discussion and in Table 8 and Figure 2. ${ }^{15}$ This analysis is conducted only for those countries where the DHS interviewed all women, not just ever-married women, because of the difficulty of bringing never-married women into the calculations when estimating 
individual-level regressions. This exclusion effectively eliminates South and Southeast Asia and the Middle East from this analysis.

The scatter-plot of the expected and observed change in early marriage is provided in Figure 2, comparing women aged 25-29 and those aged 45-49 at the time of the survey. The diagonal line in this figure represents the points at which the expected equals the observed - that is, where the change in schooling attained would appear to be sufficient to account entirely for the decline in the likelihood of marriage prior to age 18 . One striking feature of Figure 2 is the large fraction of countries - 16 out of 39 -in which the expected change exceeds the observed change (represented by points to the right of the diagonal line). These are instances in which the magnitude of the decline in early marriage between cohorts is less than would be expected given the increase in educational attainment. In roughly half of these 16 countries, the probability of early marriage actually increases between cohorts. Were education the dominant determining factor, such increases would be expected in none of the 39 countries, because schooling increased between these two cohorts everywhere. The pattern in the majority of countries, however, is that the proportion of women marrying at early ages declined from the older to the younger cohort, and this observed decline exceeds the expected decline (represented by countries to the left of the diagonal line in Figure 2). Included in this group is a set of countries, on the far left of Figure 2, in which the observed decline in early marriage is substantially greater than the expected decline. In these instances, factors other than schooling would appear to be driving the change in the timing of first marriage.

The range of regional experience evident in Figure 2 is summarized in Table 8. The regional differences are marked. In Latin America and the Caribbean, the common outcome is that the expected decline in early marriage from increased schooling far exceeds the actual decline. In many of these countries, the probability of early marriage increased rather than declined. By contrast, in about a third of the sub-Saharan African countries, the expected decline from increased schooling accounts for less than half of the actual decline. This result leaves two-thirds of the countries in which half or more of the decline in early marriage can be linked to educational increase, an impressive outcome. ${ }^{16}$ The four countries in former Soviet Asia show both small and large ratios of expected-toobserved change. In short, increases in schooling hardly appear to be the entire story, although in sub-Saharan Africa grounds are found for attributing a large share of the decline in early marriage to increased schooling.

The analysis presented in Figure 2 and Table 8 does not control for the association of schooling with other determinants. The estimated individual-level effect of schooling on early marriage will capture the effects of other variables correlated with schooling. Hence, this analysis gives an exaggerated impression of what might be accomplished through changes in schooling alone - that is, in the absence of changes in other correlated determinants of early marriage.

Even with this likely exaggeration of the impact of increased schooling on nuptiality change, the data do not reveal as powerful an association between the two as might be expected. This outcome should not come as a total surprise. A critical reading of 
the literature uncovers a number of reasons why the effect of schooling on the timing of marriage might be weaker than discussions in policy circles imply.

Good reasons can be advanced to expect a strong positive association between schooling and the timing of marriage. Some researchers note that in many early-marrying societies, school attendance is incompatible with marriage and childbearing as a matter of practice if not of policy (Lindstrom and Brambila Paz, 2001), resulting in a mechanistic positive association between educational attainment and age at marriage. For the most part, however, the countries where sizable proportions of young women marry very early are the same ones where educational attainment is low, and hence for most women a distinct gap exists between school-leaving and the earliest ages at which marriage might occur. Although schooling is often touted as enhancing girls' autonomy, empirical validation of the particular mechanisms is lacking. Education is said to give young women greater influence over the timing of marriage and choice of marriage partners (Jejeebhoy, 1995). Exposure to school is also thought to broaden a girl's perspective on the world, increasing her aspirations; present her with alternatives, for example, work opportunities; and provide her with a more Western outlook on life, which can include wanting to have a greater influence on choice of her husband (Lloyd and Mensch, 1999). Education also may give parents a strong rationale for postponement of a daughter's marriage because of her enhanced income-earning potential (Lindstrom and Brambila Paz, 2001).

Although these are sound reasons for positing that age at first marriage is postponed as years of schooling increase, there are also reasons for concern that empirical estimates of this causal effect will be upwardly biased. For one thing, educational attainment is likely to be endogenous to timing of marriage: that is, those who already intend to marry later (for whatever reason) stay in school longer, and those who intend to marry early leave school earlier to do so. Many researchers disregard this issue (see De Silva, 1997; Islam and Ahmed, 1998; Choe et al., 2001); others recognize that educational attainment may be affected by marriage and are careful about how schooling variables are specified (see Malhotra and Tsui, 1996; Malhotra, 1997; Assaad and Zouari, 2002). Even these researchers, however, do not make the point that many of the same factors determining when a girl marries are also likely to affect whether she goes to school and how long she stays there, in part because few surveys include questions that shed light on decisionmaking about schooling and marriage. One notable exception is Yabiku and colleagues' (2002) analysis of school characteristics and the timing of marriage in Nepal, in which attributes of schools - cost, number of female teachers, and teachers' credentials - are included as covariates in models of the probability of marriage. Although separate analyses are not conducted for men and women, and no attempt is made to investigate whether changes in the school environment have contributed to a delay in marriage, the Yabiku study is noteworthy in its attempt to go beyond simple measures of educational attainment.

Finally, reasons exist for questioning how much impact schooling per se should be expected to have on marriage and other aspects of family life. An analysis of the literature on education indicates that schools are not always the progressive force for 
social change that demographers generally suppose them to be (Lloyd and Mensch, 1999; Mensch et al., 2003). Thus, a more nuanced analysis of schooling and marriage is required. In particular, measures of the potential factors associated with an increase in schooling attained, such as changes in adolescent girls' gender-role attitudes, in their autonomy, and in norms about the spouse-selection process, might prove more illuminating than standard indicators of educational attainment. Data on gender-role attitudes of teachers, differences in the curriculum to which boys and girls are exposed, and analyses of the gender bias of textbooks would also be useful. The aim of gathering these data would be to distinguish communities with educational systems that reinforce the status quo from communities with educational systems that challenge existing norms.

Growth in urbanization. At the same time as age at marriage has risen, the proportion of the developing world's population living in cities has grown. The composition of the population residing in towns and cities differs in ways that would predict a later age at marriage, but increasing urbanization is also likely to be associated with a delay in marriage because of the nature of urban life. As Singh and Samara (1996) suggest, women in urban areas are exposed to modern values encouraging later marriage and are less likely to be under the influence of kin who control the timing of marriage and choice of spouse.

Although we do not have direct measures of the attributes of urban living that encourage later age at marriage, we can assess the association between changes in age at marriage and changes in the proportion of the population living in urban areas. Moreover, with available UN data we can improve on Singh and Samara's analysis of the crosssectional correlation between the changes in early marriage among those aged 20-24 and 40-44 in DHS countries and the increase in the proportion of these cohorts currently living in urban areas. The drawback of their analysis is that women aged 40-44 may have migrated since they first married. Figure 3 depicts the association between the change in the proportion of women aged 15-19 married in each of 72 countries and the change in the proportion of the population living in urban areas. Because the time interval in the surveys and censuses from which these data are derived varies, as in Tables 1 and 2, we computed the annual change. ${ }^{17}$ Although we do not know the proportion of the population residing in urban areas at the exact date of each census and survey, we do have that information within three years of the marriage data for all countries.

Somewhat surprisingly, Figure 3 indicates no association between the increase in urbanization and the decline in the proportion of women married at ages 15-19. We cannot conclude from this analysis, however, that the theoretical argument relating growing urbanization to a delay in age at marriage is without merit. To assess this relationship more precisely, time-series estimates of the social, cultural, ideational, and economic factors associated with city living are needed in addition to gross measures of urbanization.

In light of the findings presented above, changes in other factors in addition to schooling and urbanization are likely to have contributed to the observed delays in marriage. With the data at our disposal, we are unable to analyze these other factors. 
However, a review of individual country studies on age at marriage, as well as of some of the other literature on social and economic changes taking place in the developing world, provides insight into what these factors might be. It also rules out some factors that might plausibly have been expected to be related to age at marriage.

The decline in arranged marriages. Several demographers who have studied the timing of marriage in Asia have attributed the increase in women's age at marriage to changes in the marriage process. In particular, the movement away from arranged marriages is considered to have contributed to the delay in marriage (Malhotra and Tsui, 1996; Hull, 2002). In Indonesia, according to Hull (p. 8), the rise in the age at marriage "has come about due to the shift of the locus of marriage decision making from parents to children," which, incidentally, he attributes to the expansion in educational attainment among young women. It is generally believed that the process of parental selection is less time consuming than that of individual searching. Furthermore, when parents are involved in spousal selection, daughters are believed to be married off earlier because of the concern with preserving their virginity. One frequently cited reason for parental involvement in the selection is that if a daughter is allowed to search by herself for a potential partner, she is more likely to initiate sex premaritally. Another motivation for a parent involved in mate selection to marry off a daughter early is that a girl is more likely to be compliant in the choice of a spouse when she is young (UNICEF, 2001).

Although an association between age at marriage and the spouse-selection process seems reasonable, data to test for such a link are lacking. Rarely do surveys include questions that would make possible an investigation of the process of spousal selection. The 1979-80 Asian Marriage Survey, conducted in Indonesia, Pakistan, the Philippines, and Thailand among married women aged 15-45 and among a sample of their husbands, included a question about who chose the spouse. Only in Indonesia, Pakistan, and the Philippines were these data analyzed, however, and only in the first two were there substantial proportions of arranged marriages in some form. Moreover, because of the simple dichotomization of marriages into arranged/not arranged, no information was collected on whether the potential groom or bride had any input into spousal selection within marriages categorized as arranged, or whether the parents had any input into spousal selection within marriages categorized as not arranged. (Malhotra's 1991 analysis is the exception.)

The data that exist on the relative involvement of parents and young people in the selection of marriage partners suggest that in societies where arranged marriage was common, there has been a movement in recent years toward individual rather than parental choice. This decline in kin control, or increase in young women's involvement in mate selection, has been documented with survey data in Indonesia (Malhotra, 1991), Togo (Gage and Meekers, 1995), and India (Jejeebhoy and Halli, 2002), and in an ethnographic study in Nepal (Ahearn, 2001). It is also asserted to be occurring throughout sub-Saharan Africa (Lesthaeghe et al., 1989; National Research Council, 1993) and Asia (Choe et al., 2002). Although few studies provide data that permit an 
analysis of the association between trends in the marriage process and trends in age at marriage, the two are likely to be related. ${ }^{18}$

The cost of marriage: dowry and marriage markets. Researchers interested in women's age at marriage have rarely investigated whether an association exists between the time when women marry and their economic circumstances or those of their family. Abbasi and his colleagues' (2002) study conducted in Iran is an exception. Abbasi and colleagues attribute the increase in female age at marriage between 1986 and 1996 to the rise in the cost of living after the revolution and the deteriorating economic situation. They suggest that "young people tend to delay their marriage until they get a job" ( $p$. 33 ), but they do not indicate whether both young men and young women are entering the labor force or only young men.

One reason that cost may not often figure in analyses of women's age at marriage is that the groom's family bears the greater financial burden of marriage in most developing countries. To the extent that marriage involves the transfer of gifts, cash, valuables, and consumer goods, by far the more common form of exchange is from the groom's family to the bride's. Murdock's Ethnographic Atlas, initially published in the late 1960s and revised around 1980, indicates that in approximately two-thirds of the 1,267 societies catalogued, bridewealth is normative whereas dowry is prevalent in just 6 percent, although the South Asian countries where dowry is customary have considerably larger populations (cited in Bhat and Halli, 1999).

Research on the links between women's age at marriage and the cost of marriage has been limited to India and Bangladesh. In their analysis of marriage change in South India in the early 1980s, Caldwell and his colleagues (1983) argued that parents are unwilling to postpone marriage beyond the teenage years because of the increased cost of dowry for older brides, an issue that is also reported as a concern for poor parents in Bangladesh (Amin et al., 2002). Yet little quantitative analysis has been conducted on the association between the costs of dowry and women's age at marriage or, more broadly, on poverty as a factor in the timing of marriage.

Considerable research, however, focuses on providing reasons for the increase, in the second half of the twentieth century, in the prevalence and monetary value of dowry payments in South Asia. Because of declining infant and child mortality, and because women marry men who are considerably older than themselves, a "marriage squeeze" has emerged; in other words, an excess supply of women of marriageable ages now exists. Moreover, as a result of the decline in rates of maternal mortality, fewer widowers are available for women to marry. When too few men of marriageable age are available, families compete for the eligible men by paying higher dowries (Caldwell et al., 1983; Billig, 1992; Rao, 1993a and 1993b; Amin and Cain, 1997; Deolalikar and Rao, 1998; Bhat and Halli, 1999). Bhat and Halli (1999) argue that the rise in the mean age at first marriage in India is a result of the marriage squeeze. ${ }^{19}$ They contend that given the low levels of schooling in India, the increase in educational attainment has not led to a rise in age at marriage, at least not in a mechanical sense. Rather, the deficit of eligible men may induce women to stay in school. Caldwell and colleagues (1983) also maintain that the 
delay in marriage and the decline in age differences between spouses in South India are a result of the marriage squeeze. Like Bhat and Halli, they predict an increase in girls' education as Indians become more "accustomed to unmarried girls beyond the age of menarche" (Caldwell et al., 1983, p. 361).

To the degree that an association exists between women's increased age at marriage and increased schooling for girls in India, Caldwell and colleagues claim that the delay in marriage, caused by a deficit of eligible men, has been the catalyst for the expansion in girls' education, rather than the other way around, as is conventionally argued. Further investigation is needed to determine whether a marriage squeeze affects age at marriage, age differences between spouses, dowry demands, and educational attainment of young women throughout South Asia. It may well be that the nature of the response to shifts in the sex ratio of eligible men and women varies depending on local traditions surrounding marriage, household formation, and socioeconomic conditions. Interestingly, in rural Nepal, where declines in maternal mortality also have created an imbalance in individuals of marriageable age, dowry has yet to emerge as a common practice, although it is "increasingly prevalent in Kathmandu" (Ahearn, 2001, p. 89).

Changing laws, changing norms. To the best of our knowledge, no study has investigated the connection between changing laws on age at marriage and trends in marriage age across countries. Laws are often inconsistently enforced and can vary across states or administrative areas within countries, which may contribute to the complicated legal situation. A review of policies affecting marriage in seven anglophone African countries indicates that in some, such as Kenya and Nigeria, local and religious laws contradict national laws. In other countries, such as Tanzania, penal codes contradict national laws (Center for Reproductive Law and Policy, 1999). Reproductive rights advocates believe that laws specifying a minimum age at marriage are rarely enforced; rather, customary practice takes precedence over civil law (Boye et al., 1991). The data on age at marriage appear to support this view. For example, in Mali the legal age at marriage for women is now 18 and in Uganda it is 21. These are later ages than those of other countries in Africa (see IPPF and IWRAW, 2000), and an increase from 1980, when the legal age was 15 in Mali and 16 in Uganda (National Research Council, 1993). Yet according to DHS data, 65 percent of women aged 20-24 in Mali and 54 percent in Uganda were married by age 18, proportions that are among the highest in the developing world. Incidentally, despite the changes in marriage laws in these two countries, comparison of the proportions married by age 18 for 20-24-year-olds with those for 4044-year-olds reveals only a 1 percent rate of decline in Mali and a 9 percent rate of decline in Uganda, well below the average rates of decline observed for East and Southern Africa (31 percent) and West and Middle Africa (23 percent) (see Table 3 ). ${ }^{20}$

Not only are there countries with laws prohibiting early teen marriage where large proportions of women still marry at very young ages, there are also countries with very low legal ages at marriage where the prevalence of early marriage is not nearly as great. For example, the legal age at marriage in Bolivia and Peru is 14; yet only 21 percent of women are married before age 18 in Bolivia and only 19 percent in Peru. 
In some countries the actual age at which many women marry is lower than the legal age (UNICEF, 2001). In the case of Bangladesh, some speculate that the rise in age at marriage based on survey data is not real, but is rather a reflection of the inflation of the reported age at marriage among adolescent female survey respondents who are aware of the increase in the minimum legal age in 1984 from 16 to 18 (Amin, 2000). Similarly, in other countries where historically a high prevalence of teenage marriage has existed, but where the legal age at marriage is age 18 or older, the reported declines in age at marriage may be attributable to misreporting resulting from fear that families may be prosecuted for marrying daughters off at ages younger than those permitted by law. Many of the Demographic and Health Surveys contain too few 15-16-year-olds. The standard explanation for this omission is that interviewers displace 15-16-year-olds from the group eligible for individual interviews. Such a situation could also arise, however, if some married 15-16-year-olds are reported to be 17 or 18 .

Interestingly, the effort to legislate marriage age is ineffective not only when the goal is to raise the age, but also on the rare occasions when the goal is to lower the age. In Iran, the legal age at marriage for girls was reduced after the 1979 Islamic revolution from age 16 to age 9, and incentives were provided for couples to marry. However, girls' age at marriage actually increased slightly during this period (Abbasi et al., 2002).

In recent years, many developing countries have enacted changes in their laws on age at marriage. Indeed, in 55 developing countries for which data on the legal minimum age at marriage are available for both 1990 and 2000, the age is now higher in 23 countries for women and in 20 for men (see IPPF and IWRAW, 1990 and 2000). Even if laws on age at marriage are not enforced, and little association exists across countries between the legal minimum marriage age and the proportion of the population that marries early, a change in the legal age at marriage may signal a change in the discourse around marriage that might lead women and their families to contemplate a change in behavior. $^{21}$ That laws have been modified in so many countries suggests that the increased discussion of early marriage among human rights advocates, and the publicity generated by various United Nations conferences, have had an impact on global norms governing the early marriage of women (UNICEF, 2001). Just as acceptance of the value of girls' schooling has expanded to the poorest countries of the world (see Lloyd, 2005), a conviction appears to be growing that marriage should not take place during the teenage years, or at least not before age 18. According to human rights advocates, marriage before age 18 contravenes the United Nations Convention on the Rights of the Child, which defines 18 as the end of childhood, and thus defines marriage before that age as child marriage. Moreover, very early marriage is said to undermine other rights guaranteed by the Convention, including the right to be protected from physical abuse and sexual exploitation and the right not to be separated from parents against one's will (Population Council, 2002).

In theorizing about the increase in the age at first marriage among women in Africa, Hertrich (2002, p. 12) argues that in contrast to earlier generations, "recognition of a social status for women other than that of wife and mother" now exists, although the author does not provide data to support this observation. To be fair, such data are hard to 
come by. Yet changing views about women's roles seem to be a factor in the rising age at marriage. The growth in indigenous feminist movements, coupled with a globalized media - in which women are featured more prominently than in the past and greater attention is given to the situation of the "girl child"-is likely to have undermined traditional norms.

Other social and demographic changes may also be influencing attitudes toward age at marriage. An analysis of DHS data from 21 sub-Saharan African countries found that improvements in child survival are associated with later age at marriage (LeGrand and Barbieri, 2002). This finding suggests that once awareness about the decline in mortality has spread throughout a population, couples will delay marriage. Indeed, the decline in couples' desired family size, which has occurred in much of the developing world (Westoff and Bankole, 2002), ${ }^{22}$ might reasonably be thought to affect the timing of marriage because less urgency exists to begin childbearing when fertility goals are reduced. Analyses of DHS data reveal, however, that even as desired family size has fallen, the interval between marriage and first birth has declined as well (Mensch, 2003). ${ }^{23}$ Although some of this narrowing of the interval likely results from a decline in subfecundity among the newly married who are somewhat older, these data suggest that despite arguments about the improvement of women's status (noted above) considerable pressure still exists for women to prove fecundity soon after marriage.

\section{Explaining trends among men}

If the increase in women's educational attainment dominates discussions of the rise in their age at marriage, what explanation can be offered for changes in men's age at marriage? Some researchers note that, as has been the case for women, the extended educational path taken by men in recent years in many countries may contribute to the rise in their age at marriage (Hertrich, 2002). Limited data are available, however, to assess the association between changes in schooling and age at marriage among men. For this study, we have data on both schooling and marriage for only 22 sub-Saharan African countries, six Latin American and Caribbean countries, two countries from former Soviet Asia, and one Middle Eastern country where Demographic and Health Surveys have been conducted among men. ${ }^{24}$ Figure 4 graphs the absolute change in the proportion of men married at age 20 for two cohorts - men aged 20-24 and 40-44-against changes in mean grades of schooling attained by these cohorts. Contrary to Hertrich's (2002) speculation for Africa that increased schooling may have led to a rise in men's age at marriage, the association between changes in educational attainment and early marriage among men in these countries is not significant.

As with women, we consider, too, whether the increase in age at marriage observed among men is linked to urbanization. Figure 5 depicts the association between the change over the past 20 years or so in the proportion of men aged 20-24 ever married in each of 72 countries and the change in the proportion of the population living in urban areas. Because the time interval in the surveys and censuses from which these data are derived varies, as in Figure 3, we computed the annual change multiplied by 10. The 
graph indicates that the increase in urbanization and the decline in the proportion of the male population aged 20-24 who are married are not correlated.

The economic environment in developing countries is commonly invoked as the primary reason for men's delay in marrying. For example, a qualitative study of attitudes about marriage in the Philippines, Thailand, and Vietnam revealed that "poverty or lack of financial security, especially among men, was seen as a common (and sound) reason to postpone or avoid marriage" (Williams and Guest, 2002, p. 14). Few quantitative studies have investigated the association between economic conditions and the marriage patterns of men. Even studies that link employment and wages to men's age at marriage are lacking. Some evidence is found, however, of changes in the economic landscape that is consistent with men's postponement of marriage. Some scholars, for example, speculate that a reduction in landholdings in rural Asia may be a factor in delayed marriage. Increasing landlessness has forced young men to move to urban areas as well as to the Middle East in search of employment, leaving women behind (Choe et al., 2002).

In African societies, the changing nature of bridewealth, with cash payments replacing payments in kind, is said to be a contributing factor in men's delaying marriage because they need more time to acquire the necessary sums. Although the accumulation of a large bridewealth may have led to delayed marriage in the past (United Nations Department of International Economic and Social Affairs, 1990), the situation is now believed to have altered. Even where traditional bridewealth is no longer part of the marriage process, other costs have emerged for grooms, including "future help with food costs, court fees, medical treatment and younger children's school fees" (National Research Council, 1993, p. 51).

More fundamentally, a transformation in the nature of the household economy is said to have occurred in many developing countries. As has been argued for Indonesia, "the assumption in the past that marriage formed a basic productive economic unit for farming or trading has been modified by the current requirement that basic consumption needs such as capital for a house, or consumer goods, and basic educational attainments must be achieved before a marriage can 'wisely' take place” (Hull, 2002, p. 5).

In countries such as Nigeria and Sri Lanka, researchers have observed that economic considerations today are apparently a greater factor in decisions made about the timing of a man's marriage than they were earlier. In Nigeria, where a considerable decline has taken place in early marriage among men, the oil boom in the 1970s fueled a change in brides' expectations of what purchases grooms needed to make before considering marriage (National Research Council, 1993). In Sri Lanka, with its increasing industrialization, a man's job status, which was not considered important in the pastparticularly where subsistence agriculture was the dominant form of economic life-is now said to be critical in determining when he marries (De Silva, 1997).

In Egypt, where housing, furniture, and appliances are considered essential for newlyweds, and "the bulk of financial obligation[s] . . . are still borne . . . by the groom and his family," the cost of marriage is estimated to have increased dramatically in the past 30 years (Singerman and Ibrahim, 2003, p. 97), although it may be the quantity and quality of items that one is expected to acquire that have increased rather than the cost of 
basic household necessities. The proportion of individuals in the Egyptian census category of marriage registration known as katb al-kitaab, wherein the marriage is registered but the couple has yet to establish a marital residence, increased fourfold between 1986 and 1996. During this period, the annual rate of marriage barely changed. This indirect evidence suggests that rising costs may have led to a delay in the nuptials (Singerman and Ibrahim, 2003). Such evidence does not establish a firm link between the rise in the age at marriage and the costs of marriage. An important question to explore is whether the rising cost of establishing a household in Egypt and elsewhere affects the timing of marriage across all segments of society or whether the poorest members have lower expectations for what needs to be purchased before one can marry, and therefore have experienced less of an increase in age at marriage.

As with women, one also wonders whether some global changes have emerged that are influencing the timing of marriage among men. Increasing exposure to Western media may affect consumer norms and raise expectations such that young men in many societies increasingly feel obligated to postpone marriage until they have acquired the resources that are now expected for the establishment of a household. In light of the current size of the cohorts of young people in the developing world and the difficulty of ensuring adequate employment opportunities for such vast numbers, postponement of marriage among men by several years, possibly until their 30 s or beyond, may become increasingly common in many societies.

\section{Consequences of the Rising Age at Marriage}

Although we have documented and offered explanations for the trends in age at marriage, we have not examined the impact of the rising age at marriage on the lives of young people, largely because, while speculation abounds, the number of rigorous studies is extremely limited. Nonetheless, the subject is worth considering, if only to stimulate more research in this area. While separating selection effects from consequences has proven difficult, the assumption is that marriage during the teenage years is deleterious for women. Schooling may be curtailed, autonomy limited-because young brides tend to marry older men - and sexual relations uninformed and perhaps even coercive or dangerous to women's health (Clark, 2004; Jejeebhoy, 1995; Mensch, Bruce, and Greene, 1998; Singh and Samara, 1996; UNICEF, 2001). Other than increasing the risk of a premarital pregnancy, delaying marriage into the $20 \mathrm{~s}$ is generally believed to benefit women. $^{25}$

Although studies on rising ages at marriage among men are also lacking, it seems reasonable that postponement of marriage, beyond a certain point, may not be considered universally positive, even if the delay is caused by heightened expectations rather than declining economic circumstances. Indeed, late age at marriage, if it arises from limited resources, may not be viewed as desirable by young men-it may be a source of frustration, particularly where premarital sex is not condoned. Qualitative research would be valuable on the negative psychosocial effects of delaying marriage, particularly in regions, such as the Middle East, where interaction between unmarried men and women is restricted. 


\section{Age at marriage and risk for HIV infection}

In a discussion of the consequences of age at marriage, the HIV epidemic brings additional factors into consideration. Given the overriding importance of reducing the spread of HIV, we consider here what is known, as well as plausible hypotheses, about the association between women's age at marriage, the age gap between partners, and HIV risk. Delaying women's age at marriage, if it delays sexual intercourse, should reduce the age-specific rate of HIV infection among young women. In 13 of 24 sub-Saharan African countries where the probability of marrying by age 18 has declined significantly in the last 20 years, the overall proportion of women having sex by age 18 also declined significantly (Mensch et al., 2005). Furthermore, evidence exists from some studies that unmarried sexually active adolescents in sub-Saharan Africa have lower rates of HIV infection than do their married counterparts (Clark, 2004). Analysis of DHS data indicates that married adolescent girls have a higher frequency of sex than unmarried adolescent girls, are less likely to use condoms, and have older sexual partners, namely their husbands, who are more likely to be HIV-positive (Clark, 2004). Thus, even if later marriage does not lead to a delay in sexual debut, the argument is made that the nature of sexual activity among married adolescent girls puts them at higher risk for HIV infection than their unmarried counterparts.

These findings warrant at least four caveats, however. First, the assertion that the level of infection is higher among married adolescents compared with single adolescents is based on prevalence data rather than incidence data. Prevalence data obscure the possibility that young married girls may have become infected while they were single and that infected adolescent girls may be more likely to select into early marriage. Second, even if early marriage elevates HIV risks for adolescent girls, in the long run marriage may prove to be more protective than remaining single and sexually active. Data from Rakai, Uganda indicate that on average across all age groups HIV incidence is higher among the never-married than among the currently married, and highest among those previously married (Gray et al., 2004). To determine how marital status affects HIV risk, epidemiological studies must be conducted using longitudinal data. Third, the risk of acquiring HIV infection depends not only on the serostatus of one's sexual partner but also, if positive, when the partner became infected. A woman may be more likely to acquire the virus if she has sex with a newly infected partner because viral loads, which are estimated to be strongly predictive of the risk of transmission (Quinn et al., 2000; Gray et al., 2001), are high at the time of infection (Anderson, 1996). While infectivity is likely to vary systematically by age of the man, we do not have data on the infectivity rate of partners of married and unmarried adolescent girls to determine which group's partners put them at greater risk of acquiring HIV. Fourth, sexually active never-married women are more likely to change partners than are currently married women (Alan Guttmacher Institute, 1998; Ferry et al., 2001), which raises their risk of encountering an infected partner. In addition, the male partners of unmarried women are more apt to be single and, therefore, are more likely to have multiple sexual partners than are men in monogamous unions (Alan Guttmacher Institute, 2003). However, if one includes men in 
polygamous unions, then married men may be more likely to have a greater number of sexual partners than single men, as is observed in Rakai (Gray et al., 2004). ${ }^{26}$

With the data currently at hand, definitive statements about the effect of marriage delay on HIV risk cannot be made. Moreover, the association probably varies by social setting. Although marriage delay may lead to later onset of infection, it may also result in higher lifetime rates of HIV infection. An additional concern is women's HIV status when they bear children. One consequence of delayed marriage may be that women are more likely to be infected during pregnancy, although one study found no evidence to support this speculation (Clark, 2004).

As is the case for women, the health consequences of delayed marriage for men are unknown. Although marriage does not impose sexual exclusivity on men, in countries where premarital sex is prevalent a delay in marriage may increase exposure to HIV and other sexually transmitted infections because, as noted above, a greater proportion of unmarried than married men have multiple sexual partners (Appendix Table 3 in Alan Guttmacher Institute, 2003). Alternatively, in countries where norms of postpartum abstinence remain and men marry early, they may be more likely to engage in intercourse with other partners, including commercial sex workers, during the postpartum period. Clearly more research is needed on the linkages between changing age at marriage, sexual behavior, condom use, and HIV risk among both men and women.

\section{CONCLUSIONS}

During the past 30 years in most developing-country regions, substantial declines have occurred in the proportion of young men and women who are married. The clear exceptions are South America for both sexes, and South and Southeast Asia for men only.

Given the differentials in male and female ages at marriage by years of schooling and residence, we assessed whether the decline in the proportion of young people who are married is related to increases in their educational attainment and urbanization. Expansion of schooling for women has had some impact, but a considerable portion of the decline in early marriage is not explained by changes in levels of education. We asserted that a proper investigation of the association between education and age at marriage would look beyond such factors as years of schooling to what goes on within the school itself, as well as at changes in the value of education, which are likely to vary across settings.

In suggesting other factors that might account for some of the increase in age at marriage among women, we reviewed a considerable number of demographic studies. Contributory factors examined in the literature and considered here include the decline in arranged marriages, the deficit of available older men with increasing cohort size and the concomitant rise in the cost of dowries in South Asia, changes in the legal age at marriage, and a transformation in global norms about the desirability of early marriage for women. We noted that a much smaller literature is available on men's age at marriage. Although their increasing educational attainment is also believed to contribute to marriage delay, we found no evidence of this association for sub-Saharan Africa. We 
suggested that the increasing costs of establishing a household may lead men to postpone marriage.

This data analysis and review of the literature revealed that little is known about changes in the timing of marriage for men and women or about the consequences of these changes for health and other outcomes. To better understand the dynamics of union formation, demographic surveys must collect information on the social, cultural, and economic factors that affect life decisions among young people, including the contextual factors that reflect the opportunity structures available. Greater attention to the shift in the marriage process, including the apparent decline in arranged marriages and the increase in marriages based on mutual attraction, would also be useful, because both changes have implications for partners' communication and decisionmaking processes regarding family building. Gathering such data would enable the development of a more nuanced understanding of marriage, one of the key transitions in the pathway from adolescence to adulthood. 


\section{NOTES}

${ }^{1}$ Several studies predate van de Walle's call for further research. The analysis by Fricke and his colleagues (1986) of marriage-timing strategies in Pakistan is noteworthy, as is Lesthaeghe and his colleagues' (Lesthaeghe et al., 1989) investigation of nuptiality regimes in sub-Saharan Africa, which explored the timing of marriage and the practice of polygyny in great depth. This latter study was pathbreaking in linking ethnographic data (including measures of dependence on subsistence agriculture, lineage systems, inheritance, and presence of various types of chiefs) to demographic data. Malhotra and Tsui's (1996) study of the effect of marital norms - including the importance of setting up an independent household, the desire to work before marriage, and expectations about arranged marriage — on marriage timing in Sri Lanka is also an important contribution to the literature. To the best of our knowledge, it is the only analysis of marriage that uses panel data; however, although the attitudinal variables included in the event-history models are measured prior to marriage, they are still likely to be endogenous to marriage timing.

${ }^{2}$ We thank George Alter for alerting us to recent scholarship in historical demography as well as for emphasizing the uniqueness of individual family systems and for reiterating the danger of generalizing from Europe to the rest of the world (Alter, personal communication, 23 April 2004).

${ }^{3}$ By conjugal, Goode does not mean nuclear. For him, a nuclear family system is one in which no interaction takes place between relatives.

${ }^{4}$ The UN did not provide data for countries with a population of less than 140,000. Income data for all countries except East Timor were obtained from the World Bank's 2002 World Development Indicators. For East Timor, income data were obtained from the World Bank website.

${ }^{5}$ Data are not available for 15-19-year-olds in Argentina or for 20-29-year-olds in Bahrain because of nonstandard age groups. However, for other age groups, the data for these countries are included.

According to the United Nations (2003), there are a total of 152 countries in Asia, Africa, and Latin America. Thirteen of these contain a population of fewer than 140,000 inhabitants, 16 are listed by the World Bank as high-income countries, and five have no World Bank income data. Updates of country income groupings on the World Bank website $<$ www.worldbank.org/data/countryclass/classgroups.htm $>$ (accessed 30 September 2002) led us to make a few adjustments to these country groupings, including shifting Korea into the high-income group and therefore out of the developing-country group, resulting in a total of 117 countries that met our criteria.

${ }^{6}$ The DHS is limited to the household population. Ordinarily the DHS does not interview people residing in institutions, which may include military personnel and students in boarding schools and university dormitories, although the samples vary by country in this regard. The data are also subject to nonresponse error. As compared with rates for surveys in high-income countries, nonresponse rates in the DHS are low. However, the rate can be assumed to be higher for unmarried young adults, especially young adult males, than for older adults.

${ }^{7}$ Two regions (former Soviet Asia and the Middle East) were represented by only three countries, Armenia, Kazakhstan, and Turkey, and thus are not included in the regional aggregates. As indicated above, the analyses based on UN data include only countries where data for both men and women are available. Given that the vast majority of countries have data for both sexes, this restriction is not onerous. However, for analyses based on DHS data, we did not limit ourselves to countries where data were available for both sexes because we would have been left with too few countries.

${ }^{8}$ The individual country data are available from the authors.

${ }^{9}$ The weights are each country's percentage of the 2000 population aged 10-24 for all countries included in our sample for that region and not for all countries in the region (United Nations Department of Economic and Social Affairs, Population Division, 2001).

${ }^{10}$ A substantial decline in the proportion of men and women who marry early may have a small effect on the mean age at marriage for a population. For those interested in the transition to adulthood, however, such a decline is of considerable importance because of its potential impact on the lives of young people.

${ }^{11}$ The SMAM, which assumes no marriages before age 15, is computed as follows: (1) sum the proportions single and multiply this sum by five (because of the five-year age groups); (2) subtract the number of years lived by those who do not marry before age 50 ; (3) divide this total by the proportion who marry by age 50 , which is one minus the average of the proportion single at ages 45-49 and 50-54; and (4) add 15, which is the number of years lived in the single state before age 15 (see Shryock et al., 1971). 
${ }^{12}$ The median will be higher than the SMAM only in situations where a large fraction of women do not marry.

${ }^{13}$ In Ghana and Togo, for example, a decline has taken place in the proportion of young women in polygynous unions. Such unions are typically characterized by a large age gap between spouses, with women marrying young and men delaying marriage until they are able to acquire bridewealth. Thus, a decline in early marriage among women in the two countries with virtually no change or even a slight increase in marriage among men is not surprising.

${ }^{14}$ Data on grades of school attained are not available for Paraguay and Yemen; data on women were not available for Gabon at the time of this analysis.

${ }^{15}$ Regressions (1) and (2) are logit regressions. In equations (3) and (5), a predicted logit of early marriage is calculated for each woman and then transformed to a predicted probability, from which a mean is calculated. The logit regressions employ a categorical version of years of schooling $\left(S_{1}\right.$ and $\left.S_{2}\right)$, in order to allow for nonlinearities in the effect of grades of schooling attained on early marriage, with categories $0,1-$ $3,4-7$, and $8+$.

${ }^{16}$ If we restrict the analysis to those countries with moderate or substantial declines in the likelihood of marrying by age 18 - for example, those countries where the decline in the proportion of women married by age 18 is 3 percentage points or greater-the pattern is not markedly different from that shown in Table 8. In sub-Saharan Africa, for example, in slightly less than two-thirds of the countries in this restricted sample, the change in years of schooling can be credited with half or more of the decline in early marriage, an outcome similar to that shown in Table 8 .

${ }^{17}$ For ease of interpretation, in Figures 3 and 5 we multiplied the annual change by 10, which provides an average change over ten years.

${ }^{18} \mathrm{We}$ are aware of one analysis, of women in Sri Lanka, where the marriage process was included as a factor in marriage timing. Contrary to expectations, however, women who chose their own spouses married earlier than those who had arranged marriages, a pattern that the researchers note is unusual among Asian societies (Malhotra and Tsui, 1996).

${ }^{19}$ A marriage squeeze is also believed to be a factor in the increase in age at marriage in Lebanon, where 16 years of civil war and male emigration resulting from diminished work opportunities have distorted the sex ratios of individuals of marriageable age (Saxena and Kulczycki, 2004).

${ }^{20}$ Rates of decline are computed by taking the difference between the percent married by age 18 for $40-44-$ year-olds and that for 20-24-year-olds and dividing the difference by the percent married by age 18 for the 40-44-year-olds.

${ }^{21}$ Of course, in some countries, the increase in the legal age at marriage may simply reflect the prevailing circumstance. In that event, the law is simply catching up with the change in behavior.

${ }^{22}$ Francophone West Africa is the exception: other than in Togo, little change in reproductive preferences has occurred in this region in the past decade (Westoff and Bankole, 2002).

${ }^{23}$ This decline occurred among women who became pregnant and gave birth after marriage, suggesting that it is not simply due to an increase in premarital conceptions.

${ }^{24}$ Data on grades of schooling attained are not available for Gabon, although data on marriage are. Thus, only 31 countries are represented in Figure 4.

${ }^{25}$ In societies where women traditionally marry early and women's autonomy is severely limited, a delay in age at marriage may have no impact on the lives of young women. Those who marry later may be equally constrained in terms of mobility, household decisionmaking, and employment. This observation was made by Nan Astone at a March 2003 meeting of the NRC/IOM panel on "Transitions to Adulthood in Developing Countries."

${ }^{26}$ This analysis of the consequences of women's delayed marriage for HIV risk also draws on discussions that took place at a Population Council workshop on "Marriage and HIV/AIDS" on 10 November 2004. For a discussion of some of these issues see Bongaarts (2005). 


\section{REFERENCES}

Abbasi, M.J., Mehryar, A., Jones, G., and McDonald, P. 2002. "Revolution, war, and modernization: Population policy and fertility change in Iran." Journal of Population Research, 19(1), 25-46.

Ahearn, L.M. 2001. Invitations to Love: Literacy, Love Letters, and Social Change in Nepal. Ann Arbor: University of Michigan Press.

Alan Guttmacher Institute (AGI). 1998. Into a New World: Young Women's Sexual and Reproductive Lives. New York and Washington, DC: AGI.

. 2003. In Their Own Right: Addressing the Sexual and Reproductive Health Needs of Men Worldwide. New York and Washington, DC: AGI.

Amin, S. 2000. "Gender, governance and the making of a new population policy in Bangladesh." Paper presented at a panel discussion on Globalization and Some Aspects of Recent Social Changes in Rural Bangladesh, at the annual meeting of The American Rural Sociological Society, 14 August, Washington, DC.

Amin, S., and Cain, M. 1997. "The rise of dowry in Bangladesh." In G.W. Jones, R.M. Douglas, J.C. Caldwell, and R.M. D’Souza (eds.), The Continuing Demographic Transition (pp. 290-306). Oxford, England: Clarendon Press.

Amin, S., Mahmud, S., and Huq. L. 2002. "Marriage." In Baseline Survey Report on Rural Adolescents in Bangladesh: Kishori Abhijan Project. Dhaka: UNICEF and Department of Women's Affairs, Ministry of Women and Children Affairs.

Anderson, R.M. 1996. "The spread of HIV and sexual mixing patterns." In J. Mann and D. Tarantola (eds.), AIDS in the World II (Vol. II, pp. 71-86). New York: Oxford University Press.

Anderson, S. 2003. "Why dowry payments declined with modernization in Europe but are rising in India." Journal of Political Economy, 111(2), 269-310.

Assaad, R., and Zouari, S. 2002. "The timing of marriage, fertility, and female labor force participation in urban Morocco." Paper presented at the Economic Research Forum Ninth Annual Conference, 26-28 October, Sharjah, UAE.

Becker, G. 1973. "A theory of marriage." In T.W. Schultz (ed.), Economics of the Family: Marriage, Children and Human Capital (pp. 299-344). Chicago: The University of Chicago for the National Bureau of Economic Research.

Bhat, P.N.M. and Halli, S.S. 1999. "Demography of brideprice and dowry: Causes and consequences of the Indian marriage squeeze.” Population Studies, 53(2), 129148.

Billig, M.S. 1992. "The marriage squeeze and the rise of groomprice in India's Kerala State." Journal of Comparative Family Studies, 23(2), 197-216.

Blanc, A.K. and Rutenberg, N. 1990. "Assessment of the quality of data on age at first sexual intercourse, age at first marriage and age at first birth in the Demographic and Health Surveys." In An Assessment of DHS-I Data Quality (pp. 41-79). Columbia, MD: Institute of Resource Development/Macro Systems.

Bongaarts, J. 2005. "Marriage, sexual behavior, and HIV epidemics in sub-Saharan Africa." Unpublished. 
Boulier, B.L. and Rosenzweig, M.R. 1984. "Schooling, search, and spouse selection: Testing economic theories of marriage and household behavior." The Journal of Political Economy, 92(4), 712-732.

Boye, A.K., Hill, K., Isaacs, S., and Gordis, D. 1991. "Marriage law and practice in the Sahel." Studies in Family Planning, 22(6), 343-349.

Brien, M.J. and Lillard. L.A. 1994. "Education, marriage, and first conception in Malaysia." The Journal of Human Resources, 34(4), 1167-1204.

Caldwell, J., Reddy, P.H., and Caldwell, P. 1983. "The causes of marriage change in South India." Population Studies, 37(3), 343-361.

Casterline, J.B. 1994. "Fertility transition in Asia." In T. Locoh and V. Hertrich (eds.), The Onset of Fertility Transition in Sub-Saharan Africa (pp. 69-86). Liège, Belgium: Ordina.

Center for Reproductive Law and Policy. 1999. Adolescent Reproductive Rights: Laws and Policies to Improve Their Health and Lives. New York: Center for Reproductive Law and Policy.

Choe, M.K., Thapa, S., and Achmad, S. 2001. Early marriage and childbearing in Indonesia and Nepal (East-West Center Working Papers Population Series, No. 108-115). Honolulu, HI: East-West Center.

Choe, M.K., Westley, S.B., and Retherford, R.D. 2002. Tradition and Change in Marriage and Family Life: The Future of Population in Asia. Honolulu, HI: East-West Center.

Clark, S. 2004. "Early marriage and HIV risks in sub-Saharan Africa." Studies in Family Planning, 35(3), 149-160.

Coale, A.J., and Treadway, R. 1986. "A summary of the changing distribution of overall fertility, marital fertility, and the proportion married in the provinces of Europe." In A.J. Coale and S.C. Watkins (eds.), The Decline of Fertility in Europe: The Revised Proceedings of a Conference on the Princeton European Fertility Project (pp. 31-181). Princeton, NJ: Princeton University Press.

Dahal, D.R., Fricke, T., and Thornton, A. 1993. "The family contexts of marriage timing in Nepal." Ethnology, 32(4), 305-323.

Das Gupta, M. 1997. "Kinship systems and demographic regimes." In D.I. Kertzer and T. Fricke (eds.), Anthropological Demography: Toward a New Synthesis (pp. 3652). Chicago and London: University of Chicago Press.

Deolalikar, A.B., and Rao, V. 1998. "The demand for dowries and bride characteristics in marriage: Empirical estimates for rural South-Central India." In M. Krishnaraj, R. Sudarshan, and A. Shariff (eds.), Gender, Population, and Development (pp. 122-140). Oxford, England: Oxford University Press.

De Silva, W.I. 1997. "The Ireland of Asia: Trends in marriage timing in Sri Lanka." Asia-Pacific Population Journal, 12(2), 3-24.

Ehmer, J. 2002. "Marriage." In D.I. Kertzer and M. Barbagli (eds.), Family Life in the Long Nineteenth Century 1789-1913, Volume two: The History of the European Family (pp. 282-321). New Haven and London: Yale University Press. 
Ferry, B., Caraël, M., Buvé, A., Auvert, B., Laourou, M., Kanhonou, L., de Loenzien, M., Akam, E., Chege, J., and Kaona, F., for the Study Group on Heterogeneity of HIV Epidemics in African Cities. 2001. "Comparison of key parameters of sexual behaviour in four African urban populations with different levels of HIV infection." AIDS, 15(supplement 4), S41-S50.

Fricke, T.E., Syed, S.H., and Smith, P.C. 1986. "Rural Punjabi social organization and marriage timing strategies in Pakistan." Demography, 23(4), 489-508.

Gage, A.J., and Meekers, D. 1995. "The changing dynamics of family formation: Women's status and nuptiality in Togo." In P. Makinwa-Adebusoye and A.-M. Jensen (eds.), Women and Demographic Change in Sub-Saharan Africa (pp. 1538). Liège, Belgium: International Union for the Scientific Study of Population.

Goode, W.J. 1963. World Revolution and Family Patterns. New York: Free Press.

Gray, R.H., Wawer, M.J., Brookmeyer, R., Sewankambo, N.K., Serwadda, D., WabwireMangen, F., Lutalo, T., Li, X., vanCott, T., and Quinn, T.C. 2001. "Probability of HIV-1 transmission per coital act in monogamous, heterosexual, HIV-1discordant couples in Rakai, Uganda." The Lancet, 357(9263), 1149-1153.

Gray, R., Nalugoda, F., Serwadda, D., and Wawer, M. 2004. "Marriage and HIV risk: Data from Rakai, Uganda." Paper presented at Workshop on Marriage and HIV/AIDS, 10 November. New York: Alan Guttmacher Institute.

Guinnane, T. 1991. "Re-thinking the Western European marriage pattern: The decision to marry in Ireland at the turn of the twentieth century." Journal of Family History 16(1), 47-64.

Gutmann, M.P. and Leboutte, R. 1984. "Rethinking protoindustrialization and the family." Journal of Interdisciplinary History 14(3), 587-607.

Hajnal, J. 1965. "European marriage patterns in perspective." In D.V. Glass and D.E.C. Eversley (eds.), Population in History: Essays in Historical Demography (pp. 101-143). London: Edward Arnold.

Heaton, T.B., Forste, R., and Otterstrom, S.M. 2002. "Family transitions in Latin America: First intercourse, first union, and first birth." International Journal of Population Geography, 8, 1-15.

Hertrich, V. 2002. "Nuptiality and gender relationships in Africa: An overview of first marriage trends over the past 50 years." Paper presented at the annual meeting of the Population Association of America, 9-11 May, Atlanta.

Hull, T.H. 2002. "The marriage revolution in Indonesia." Paper presented at the annual meeting of the Population Association of America, 9-11 May, Atlanta.

International Center for Research on Women. 2004. "Too young to wed: Child marriage in their own words." $<$ http://www.icrw.org/photoessay/html/intro.htm>. Accessed August 2004.

International Planned Parenthood Federation (IPPF) and International Women's Rights Action Watch (IWRAW). 1990. Reproductive Rights. The Hubert H. Humphrey Institute of Public Affairs at University of Minnesota. Suffolk, England: Lavenham Press. 
2000. Reproductive Rights 2000. The Hubert H. Humphrey Institute of Public Affairs at University of Minnesota. London: Terracotta Press.

Islam, M.N., and Ahmed, A.U. 1998. "Age at first marriage and its determinants in Bangladesh." Asia-Pacific Population Journal, 13(2), 73-92.

Jejeebhoy, S. 1995. "Education and women's age at marriage." In S. Jejeebhoy, Women's Education, Autonomy, and Reproductive Behaviour: Experience from Developing Countries (pp. 60-77). Oxford, England: Clarendon Press.

Jejeebhoy, S.J., and Halli, S.S. 2005. "Marriage patterns in rural India: Influence of sociocultural context." In The Changing Transitions to Adulthood in Developing Countries: Selected Studies (Chapter 6). Forthcoming.

Kertzer, D.I. and Hogan, D.P. 1991. "Reflections on the European marriage pattern: Sharecropping and proletarianization in Casalecchio, Italy, 1861-1921." Journal of Family History, 16(1), 31-45.

Kishor, S. 2003. "Uses and limitations of DHS data on age and characteristics of first marriages." Paper presented at UNICEF Global Consultation on Indicators: Female Genital Mutilation/Cutting and Early Marriage, 11-13 November, New York.

LeGrand, T.K. and Barbieri, M. 2002. "The possible effects of child survival on women's ages at first union and childbirth in sub-Saharan Africa." European Journal of Population, 18, 361-386.

Lesthaeghe, R.J., Kaufman, G., and Meekers, D. 1989. "The nuptiality regimes in subSaharan Africa." In R.J. Lesthaeghe (ed.), Reproduction and Social Organization in Sub-Saharan Africa (pp. 238-333). Berkeley: University of California Press.

Lindstrom, D.P., and Brambila Paz, C. 2001. "Alternative theories of the relationship of schooling and work to family formation: Evidence from Mexico." Social Biology, 48(3-4), 278-297.

Lloyd, C.B. (ed.). 2005. "Schooling." In Growing Up Global: The Changing Transitions to Adulthood in Developing Countries (pp. 67-167). National Research Council and Institute of Medicine, Panel on Transitions to Adulthood in Developing Countries. Washington, DC: National Academies Press.

Lloyd, C.B. and Mensch, B.S. 1999. "Implications of formal schooling for girls' transitions to adulthood in developing countries." In C.H. Bledsoe, J.B. Casterline, J.A. Johnson-Kuhn, and J.G. Haaga (eds.), Critical Perspectives on Schooling and Fertility in the Developing World (pp. 80-104). Washington, DC: National Academy Press.

Lynch, K.A. 1991. "The European marriage pattern in the cities: Variations on a theme by Hajnal." Journal of Family History, 16(1), 79-96.

Malhotra, A. 1991. "Gender and changing generational relations: Spouse choice in Indonesia." Demography, 28(4), 549-570. - 1997. "Gender and the timing of marriage: Rural-urban differences in Java." Journal of Marriage and the Family, 59(2), 434-450. 
Malhotra, A. and Tsui, A.O. 1996. "Marriage timing in Sri Lanka: The role of modern norms and ideas." Journal of Marriage and the Family, 58(2), 476-490.

Mensch, B.S., Bruce, J., and Greene, M.E. 1998. The Uncharted Passage: Girls' Adolescence in the Developing World. New York: Population Council.

Mensch, B.S. 2003. "Trends in the timing of first marriage." Paper presented at the WHO, UNFPA, and Population Council Technical Consultation on Married Adolescents, 9 December, Geneva.

Mensch, B.S., Ibrahim, B.L., Lee, S.M., and El-Gibaly, O. 2003. "Gender-role attitudes among Egyptian adolescents." Studies in Family Planning, 34(1), 8-18.

Mensch, B.S., Grant, M.J., Blanc, A.K., and Clark, S. 2005. "The changing context of sexual initiation in sub-Saharan Africa." Paper accepted for presentation at the $25^{\text {th }}$ International Union for the Scientific Study of Population International Population Conference, Tours, July.

Montgomery, M.R., and Sulak, D.B. 1989. "Female first marriage in East and SoutheastAsia: A Kiefer-Neumann Model." Journal of Development Economics, 30(2), 225-240.

National Research Council, Committee on Population. 1993. "Marriage: New forms, new ambiguities." In C.H. Bledsoe and B. Cohen (eds.), Social Dynamics of Adolescent Fertility in Sub-Saharan Africa (pp. 37-68). Washington, DC: National Academy Press.

Population Council. 2002. Background document prepared for Working Group on Girls, United Nations Special Session on Children, 10 May, New York.

Preston, S.H., Heuveline, P., and Guillot, M. 2001. Demography: Measuring and Modeling Population Processes. Malden, MA: Blackwell Publishing.

Quinn, T.C., Wawer, M.J., Sewenkambo, N., Serwadda, D., Li, C., Wabwire-Mangen, F., Meehan, M.O., Lutalo, T., and Gray, R.H. 2000. "Viral load and heterosexual transmission of human immunodeficiency virus type 1." The New England Journal of Medicine, 342(13), 921-929.

Rao, V. 1993a. "Dowry 'inflation' in rural India: A statistical investigation." Population Studies, 47, 283-293.

- 1993b. "The rising price of husbands: A hedonic analysis of dowry increases in rural India." Journal of Political Economy, 101(4), 666-677.

Rashad, H. and Osman, M. 2003. "Nuptiality in Arab countries: Changes and implications." In N. S. Hopkins (ed.), Cairo Papers in Social Science: The New Arab Family (pp. 20-50). Cairo: The American University in Cairo Press.

Rosero-Bixby, L. 1996. "Nuptiality trends and fertility transition in Latin America." In J.M. Guzman, S. Singh, G. Rodriguez, and E.A. Pantelides (eds.), The Fertility Transition in Latin America (pp. 135-150). Oxford, England: Clarendon Press.

Saxena, P.C. and Kulczycki, A. 2004. "Nuptiality transition and marriage squeeze in Lebanon: Consequences of sixteen years of civil war." Journal of Comparative Family Studies, 35(2), 241-258.

Shryock, H.S., Siegel, J.S., et al. 1971. The Methods and Materials of Demography. Washington, DC: United States Bureau of the Census. 
Singerman, D. and Ibrahim, B. 2003. "The costs of marriage in Egypt: A hidden dimension in the new Arab demography." In N.S. Hopkins (ed.), Cairo Papers in Social Science: The New Arab Family (pp. 80-116). Cairo: The American University in Cairo Press.

Singh, S. and Samara, R. 1996. "Early marriage among women in developing countries." International Family Planning Perspectives, 22(4), 148-157, 175.

Smith, P.C. 1983. "The impact of age at marriage and proportions marrying on fertility." In R.A. Bulatao and R.D. Lee with P.E. Hollerbach and J. Bongaarts (eds.), Determinants of Fertility in Developing Countries (pp. 473-531). New York: Academic Press.

United Nations. 2003. World Population Prospects: The 2002 Revision, Volume 1: Comprehensive Tables. New York: United Nations.

United Nations Children's Fund (UNICEF). 2001. Early Marriage: Child Spouses. Florence, Italy: UNICEF, Innocenti Research Center.

United Nations Commission on Population and Development. 2002. Concise Report on World Population Monitoring 2002: Reproductive Rights and Reproductive Health with Special Reference to Human Immunodeficiency Virus/Acquired Immunodeficiency Syndrome (HIV/AIDS). Report of the Secretary General (E/CN.9/2002/2). Presented at the Commission on Population and Development, United Nations, New York, 1-5 April.

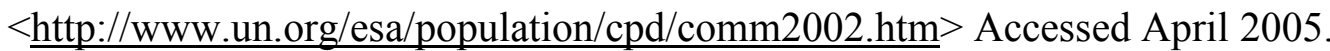

United Nations, Department of International Economic and Social Affairs (UNDIESA). (1990). Patterns of First Marriage: Timing and Prevalence. New York: United Nations.

United Nations, Department of Economic and Social Affairs, Population Division. 2000. Database on marriage patterns. POP/1/DB/2000/3.

- 2001. World Population Prospects: The 2000 Revision (CD-ROM). File 1: Total population by age group, major area, region, and country, 1950-2050 (in thousands), estimates 1950-2000 (POP/DB/WPP/Rev.2000/3/F1). 2004. World Fertility Report: 2003. New York: United Nations.

van de Walle, E. 1993. "Recent trends in marriage ages." In K.A. Foote, K.H. Hill, and L.G. Martin (eds.), Demographic Change in Sub-Saharan Africa (pp. 117-152). Washington, DC: National Academy Press.

van de Walle, E. and Meekers, D. 1994. "Marriage drinks and kola nuts." In C. Bledsoe and G. Pison (eds.), Nuptiality in Sub-Saharan Africa: Contemporary Anthropological and Demographic Perspectives (pp. 57-73). Oxford, England: Clarendon Press.

Watkins, S.C. 1986. "Regional patterns of nuptiality in Western Europe." In A.J. Coale and S.C. Watkins (eds.), The Decline of Fertility in Europe: The Revised Proceedings of a Conference on the Princeton European Fertility Project (pp. 314-336). Princeton, NJ: Princeton University Press.

Westoff, C.F. 2003. Trends in Marriage and Early Childbearing in Developing Countries. (DHS Comparative Reports No. 5). Calverton, MD: ORC Macro. 
Westoff, C.F. and Bankole, A. 2002. Reproductive Preferences in Developing Countries at the Turn of the Century (DHS Comparative Reports No. 2). Calverton, MD: ORC Macro.

Williams, L., and Guest, M.P. 2002. Why Marry? Attitudes of Urban Middle-class Respondents in Vietnam, Thailand, and the Philippines (Population and Development Program Working Paper Series No. 01.01). Ithaca, NY: Cornell University, Department of Rural Sociology.

World Bank. 2002. World Development Indicators 2002. Washington, DC: The World Bank.

Wrigley, E.A., Davies, R.S., Oeppen, J.E., and Schofield. R.S. 1997. English Population History from Family Reconstitution 1580-1837. Cambridge, UK: Cambridge University Press.

Yabiku, S.T. 2003. Neighbors or Neighborhoods? Effects on Marriage Timing in Nepal. Paper presented at the annual meeting of the Population Association of America, Minneapolis.

Yabiku, S.T., Axinn, W.G., Ghimire, D.J., and Robinson, K.D. 2002. "School characteristics and marriage timing." Paper presented at the annual meeting of the Population Association of America, 9-11 May, Atlanta. 
Table 1: Percentage of women ever married, by age, time period, and region ${ }^{a}$ (weighted ${ }^{b}$ averages)

\begin{tabular}{|c|c|c|c|c|c|c|c|c|c|c|}
\hline Region & $\begin{array}{l}\text { Percent of } \\
\text { region's } \\
\text { population } \\
\text { represented }\end{array}$ & \multicolumn{3}{|c|}{ Ages 15-19 } & \multicolumn{3}{|c|}{ Ages 20-24 } & \multicolumn{3}{|c|}{ Ages 25-29 } \\
\hline Eastern/Southern Africa & 89.8 & 37.5 & 24.5 & -0.75 & 77.2 & 65.6 & -0.71 & 89.2 & 83.4 & -0.38 \\
\hline Western/Middle Africa & 30.8 & 53.0 & 38.4 & -0.89 & 85.1 & 78.6 & -0.40 & 93.5 & 92.3 & -0.05 \\
\hline South-central/Southeastern Asia & 93.3 & 39.6 & 32.3 & -0.64 & 80.6 & 77.4 & -0.30 & 93.7 & 93.4 & -0.02 \\
\hline Former Soviet Asia $^{\mathrm{e}}$ & 37.8 & 9.4 & 9.6 & 0.02 & 61.2 & 54.0 & -0.70 & 85.0 & 80.7 & -0.42 \\
\hline \multicolumn{11}{|l|}{ Latin America and Caribbean } \\
\hline Caribbean/Central America & 87.5 & 20.6 & 18.1 & -0.27 & 59.4 & 56.1 & -0.35 & 81.0 & 79.3 & -0.20 \\
\hline Total & 86.5 & 26.6 & 20.8 & -0.48 & 70.8 & 63.9 & -0.56 & 91.6 & 89.4 & -0.18 \\
\hline 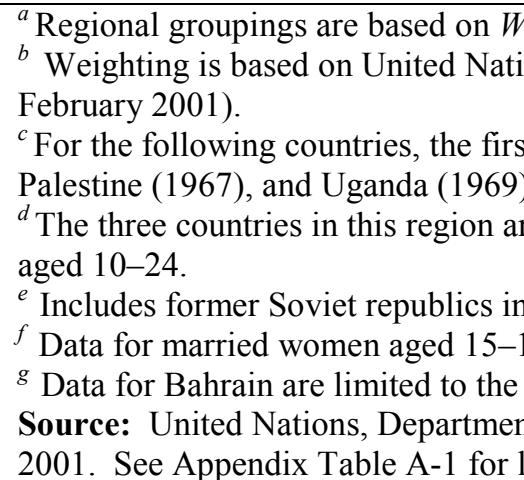 & $\begin{array}{l}\text { Vorld Populatic } \\
\text { ions populatior } \\
\text { st survey/censu } \\
\text { ). } \\
\text { re China, Mon } \\
\text { n South-central } \\
19 \text { are not avai } \\
15-19 \text { age gro } \\
\text { nt of Economic }\end{array}$ & $\begin{array}{l}\text { n Prospect } \\
\text { estimates } \\
\text { S was cond } \\
\text { yolia, and I } \\
\text { and Weste } \\
\text { able for At } \\
\text { up; other d } \\
\text { and Socia }\end{array}$ & $\begin{array}{l}\text { Icted befor } \\
\text { orth Korea } \\
\text { n Asia. } \\
\text { gentina for } \\
\text { ta are for } n \\
\text { Affairs, Po }\end{array}$ & $\begin{array}{l}\text { 1970: Ca } \\
\text { Data are a } \\
\text { me period } \\
\text { nstandard } \\
\text { ulation Di }\end{array}$ & $\begin{array}{l}\text { odia (1962) } \\
\text { lable only } \mathrm{f} \\
\text { e groups. } \\
\text { ion databas }\end{array}$ & $\begin{array}{l}\text { had (196 } \\
\text { China, wh }\end{array}$ & $\begin{array}{l}\text { Gabon }(1) \\
\text { h contains }\end{array}$ & ), Kenya & $\begin{array}{l}\text { /Rev. 2000/ } \\
\text { 69), Namibi } \\
\text { e region's p }\end{array}$ & $\begin{array}{l}\text { F1. } \\
\text { (1960), } \\
\text { pulation } \\
\text { es, } 1960\end{array}$ \\
\hline
\end{tabular}


Table 2: Percentage of men ever married, by age, time period, and region (weighted averages)

Ages 20-24

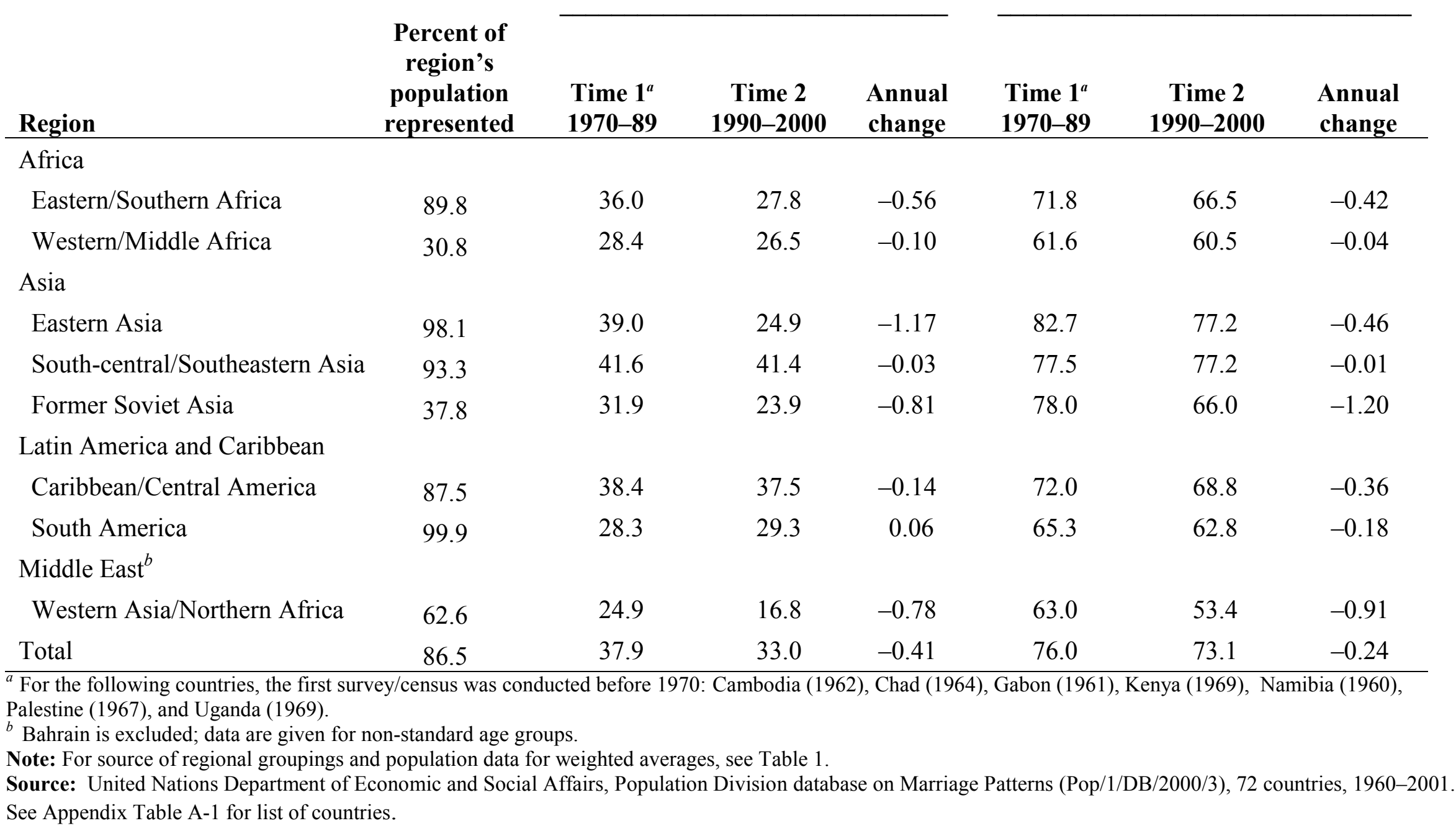


Table 3: Percentage of women married by ages 18,20 , and 25 , by age at time of survey and region (weighted averages)

\begin{tabular}{|c|c|c|c|c|c|c|c|c|c|}
\hline \multirow[b]{2}{*}{ Region } & \multirow[b]{2}{*}{$\begin{array}{l}\text { Percent of } \\
\text { region's } \\
\text { population } \\
\text { represented }\end{array}$} & \multicolumn{3}{|c|}{ Age 18} & \multicolumn{3}{|c|}{ Age 20} & \multicolumn{2}{|c|}{ Age 25} \\
\hline & & 20-24 & 30-34 & $40-44$ & 20-24 & 30-34 & $40-44$ & $30-34$ & $40-44$ \\
\hline \multicolumn{10}{|l|}{ Africa } \\
\hline Eastern/Southern Africa & 91.7 & 36.5 & 45.7 & 52.8 & 54.6 & 62.9 & 69.2 & 83.6 & 88.2 \\
\hline Western/Middle Africa $^{a}$ & 75.2 & 44.8 & 55.0 & 57.9 & 60.1 & 69.5 & 73.6 & 88.7 & 92.6 \\
\hline \multicolumn{10}{|l|}{ Asia } \\
\hline $\begin{array}{l}\text { South-central/Southeastern } \\
\text { Asia }\end{array}$ & 86.0 & 41.5 & 54.2 & 57.6 & 59.5 & 71.0 & 74.3 & 90.4 & 92.4 \\
\hline Former Soviet Asia & 68.4 & 15.9 & 10.9 & 14.2 & 49.9 & 39.7 & 45.9 & 87.8 & 87.2 \\
\hline \multicolumn{10}{|l|}{ Latin America and Caribbean } \\
\hline Caribbean/Central America & 21.0 & 34.9 & 35.7 & 38.4 & 53.3 & 53.7 & 58.1 & 82.3 & 82.5 \\
\hline South America & 74.1 & 22.7 & 22.5 & 21.9 & 38.0 & 39.7 & 39.6 & 73.1 & 75.2 \\
\hline \multicolumn{10}{|l|}{ Middle East } \\
\hline Western Asia/Northern Africa & 54.8 & 23.2 & 35.1 & 45.5 & 39.8 & 52.2 & 64.2 & 81.7 & 87.2 \\
\hline Total & 59.8 & 37.7 & 48.2 & 52.0 & 55.5 & 65.0 & 69.1 & 87.2 & 89.8 \\
\hline
\end{tabular}

${ }^{a}$ Gabon is excluded: data on women were unavailable at time of this analysis.

Note: For source of regional groupings and population data for weighted averages, see Table 1.

Source: DHS tabulations, 51 countries, 1990-2001. See Appendix Table A-1 for list of countries. 
Table 4: Percentage of men married by ages 20,25, and 30, by age at time of survey and region (weighted averages)

\begin{tabular}{|c|c|c|c|c|c|c|c|c|}
\hline \multirow[b]{2}{*}{ Region } & \multirow{2}{*}{$\begin{array}{l}\text { Percent of } \\
\text { region's } \\
\text { population } \\
\text { represented }\end{array}$} & \multicolumn{3}{|c|}{ Age 20} & \multicolumn{2}{|c|}{ Age 25} & \multicolumn{2}{|c|}{ Age 30} \\
\hline & & 20-24 & 30-34 & $40-44$ & 30-34 & $40-44$ & 30-34 & $40-44$ \\
\hline \multicolumn{9}{|l|}{ Africa } \\
\hline Eastern/Southern Africa & 69.5 & 13.8 & 20.0 & 21.3 & 59.3 & 61.0 & 86.7 & 87.7 \\
\hline Western/Middle Africa & 75.5 & 12.0 & 16.2 & 17.5 & 47.7 & 50.9 & 77.0 & 76.5 \\
\hline \multicolumn{9}{|l|}{ Latin America and Caribbean } \\
\hline Caribbean/Central America & 13.7 & 22.2 & 20.4 & 21.9 & 55.3 & 58.0 & 76.0 & 80.1 \\
\hline South America & 60.3 & 14.0 & 18.2 & 10.8 & 58.7 & 57.4 & 80.7 & 85.6 \\
\hline Total & 60.5 & 13.5 & 18.1 & 16.9 & 54.8 & 56.2 & 81.1 & 82.7 \\
\hline
\end{tabular}

Note: For source of regional groupings and population data for weighted averages, see Table 1.

Source: DHS tabulations, 29 countries, 1994-2001. See Appendix Table A-1 for list of countries. 
Table 5: Percentage of women aged 20-24 married by age 18, by years of schooling and region (weighted averages)

\begin{tabular}{|c|c|c|c|c|}
\hline \multirow[b]{2}{*}{ Region } & \multirow{2}{*}{$\begin{array}{c}\text { Percent of } \\
\text { region's } \\
\text { population } \\
\text { represented }\end{array}$} & \multicolumn{3}{|c|}{ Years of schooling } \\
\hline & & $\mathbf{0}-\mathbf{3}$ & $4-7$ & $8+$ \\
\hline \multicolumn{5}{|l|}{ Africa } \\
\hline Eastern/Southern Africa & 91.7 & 51.2 & 38.6 & 12.6 \\
\hline Western/Middle Africa ${ }^{a}$ & 75.2 & 70.5 & 36.8 & 14.1 \\
\hline \multicolumn{5}{|l|}{$\operatorname{Asia}^{b}$} \\
\hline South-central/Southeastern $\mathrm{Asia}^{c}$ & 28.0 & 55.7 & 44.0 & 17.3 \\
\hline \multicolumn{5}{|l|}{ Latin America and Caribbean } \\
\hline Caribbean/Central America & 21.0 & 55.5 & 43.9 & 14.7 \\
\hline South America & 74.1 & 41.7 & 30.3 & 10.8 \\
\hline \multicolumn{5}{|l|}{ Middle East } \\
\hline Western Asia/Northern Africa ${ }^{d}$ & 49.6 & 38.9 & 25.6 & 6.4 \\
\hline Total & 34.4 & 53.2 & 37.6 & 13.5 \\
\hline
\end{tabular}

${ }^{a}$ Gabon is excluded: data on women were unavailable at the time of this analysis.

${ }^{b}$ Former Soviet Asia is excluded: too few women have less than eight years of schooling.

${ }^{c}$ India and Pakistan are excluded: the "all-women" weight is lacking.

${ }^{d}$ Yemen is excluded: the "all-women" weight is lacking.

Note: For source of regional groupings and population data for weighted averages, see Table 1.

Source: DHS tabulations, 44 countries, 1990-2001. See Appendix Table A-1 for list of countries. 
Table 6: Percentage of women aged 20-24 married by age 18, by rural-urban residence and region (weighted averages)

\begin{tabular}{|c|c|c|c|}
\hline \multirow[b]{2}{*}{ Region } & \multirow{2}{*}{$\begin{array}{l}\text { Percent of } \\
\text { region's } \\
\text { population } \\
\text { represented }\end{array}$} & \multicolumn{2}{|c|}{ Residence } \\
\hline & & Rural & Urban \\
\hline \multicolumn{4}{|l|}{ Africa } \\
\hline Eastern/Southern Africa & 91.7 & 41.0 & 25.3 \\
\hline Western/Middle Africa ${ }^{a}$ & 75.2 & 52.2 & 30.1 \\
\hline \multicolumn{4}{|l|}{ Asia } \\
\hline South-central/Southeastern Asia & 86.0 & 48.4 & 24.3 \\
\hline Former Soviet Asia & 68.4 & 17.9 & 13.9 \\
\hline \multicolumn{4}{|l|}{ Latin America and Caribbean } \\
\hline Caribbean/Central America & 21.0 & 44.5 & 27.6 \\
\hline South America & 74.1 & 31.4 & 20.3 \\
\hline \multicolumn{4}{|l|}{ Middle East } \\
\hline Western Asia/Northern Africa & 54.8 & 28.3 & 16.7 \\
\hline Total & 59.8 & 44.4 & 23.9 \\
\hline
\end{tabular}

${ }^{a}$ Gabon is excluded: data on women were unavailable at the time of this analysis.

Note: For source of regional groupings and population data for weighted averages, see Table 1.

Source: DHS tabulations, 51 countries, 1990-2001. See Appendix Table A-1 for list of countries. 
Table 7: Percentage of men aged 20-24 married by age 20, by years of schooling, rural-urban residence, and region (weighted averages)

\begin{tabular}{|c|c|c|c|c|c|c|}
\hline \multirow[b]{2}{*}{ Region } & \multirow{2}{*}{$\begin{array}{l}\text { Percent of } \\
\text { region's } \\
\text { population } \\
\text { represented }\end{array}$} & \multicolumn{3}{|c|}{ Years of schooling } & \multicolumn{2}{|c|}{ Residence } \\
\hline & & $\mathbf{0}-\mathbf{3}$ & 4-7 & $8+$ & Rural & Urban \\
\hline \multicolumn{7}{|l|}{ Africa } \\
\hline Eastern/Southern Africa & 69.5 & 20.9 & 16.7 & 6.5 & 15.5 & 8.2 \\
\hline Western/Middle Africa ${ }^{a}$ & 75.5 & 21.0 & 14.5 & 6.0 & 16.0 & 5.1 \\
\hline \multicolumn{7}{|l|}{ Latin America and Caribbean } \\
\hline Caribbean/Central America & 13.7 & 24.6 & 30.9 & 13.9 & 26.5 & 18.2 \\
\hline South America & 60.3 & 20.7 & 18.0 & 10.0 & 13.4 & 14.0 \\
\hline
\end{tabular}


Table 8: Percentage distribution of the ratio of expected ${ }^{a}$ to observed difference in the proportion of women aged 25-29 and 45-49 married by age 18 , by region ${ }^{b}$ (weighted distribution)

\section{Ratio of expected ${ }^{a}$ to observed difference}

\begin{tabular}{lccccc} 
Region & $\mathbf{< . 5 0}$ & $\mathbf{0 . 5 0 - 0 . 9 9}$ & $\mathbf{1 . 0 0}+^{c}$ & Total & (number of countries) \\
\hline Latin America and Caribbean & 0 & 14 & 86 & 100 & $(9)$ \\
Former Soviet Asia $_{\text {Sub-Saharan Africa }}{ }^{d}$ & 63 & 0 & 37 & 100 & $(4)$ \\
All regions & 32 & 26 & 42 & 100 & $(26)$ \\
\hline
\end{tabular}

${ }^{a}$ The expected difference is derived from individual-level regressions for each cohort. It is the amount of change expected in the proportion marrying before age 18 if the association between early marriage and educational attainment were to remain stable across cohorts while the educational distribution changes across cohorts as observed.

${ }^{b}$ The Middle East and South-central and Southeastern Asia are excluded because they are limited to ever-married samples.

${ }^{c}$ Includes those countries where the observed probability of early marriage increased between the two cohorts.

${ }^{d}$ Sub-Saharan Africa combines Western/Middle and Eastern/Southern Africa. Gabon is excluded because data on women were unavailable at time of this analysis.

Note: For source of regional groupings and population data for weighted averages, see Table 1.

Source: DHS tabulations, 39 countries, 1990-2001. See Appendix Table A-1 for list of countries. 
Figure 1: Association between change in percentage of women aged 20-24 and 40-44 married by age 18 and change in grades of school they attained

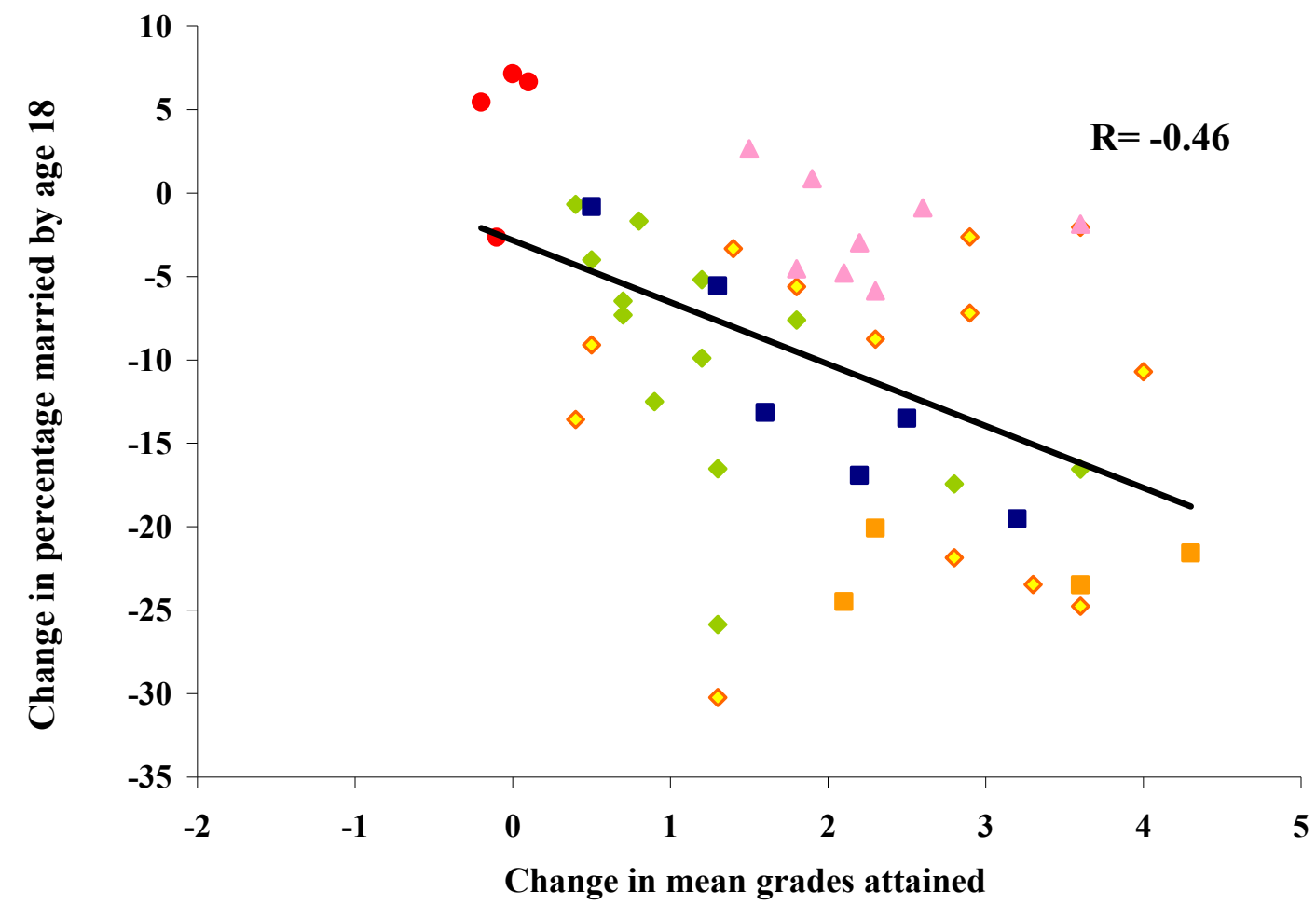

Former Soviet Asia

$\rightarrow$ Western/Middle Africa

$\diamond$ Eastern/Southern Africa

$\triangle$ Latin America and Caribbean

- South-central/Southeastern Asia Middle East

Source: DHS tabulations, 49 countries, 1990-2001. See Appendix Table A-1 for list of countries. Paraguay and Yemen are excluded because they are missing schooling data. Gabon is excluded because data on women were unavailable at time of this analysis. 
Figure 2: Association between observed and expected ${ }^{\mathrm{a}}$ change in percentage of women aged 25-29 and 45-49 married by age 18

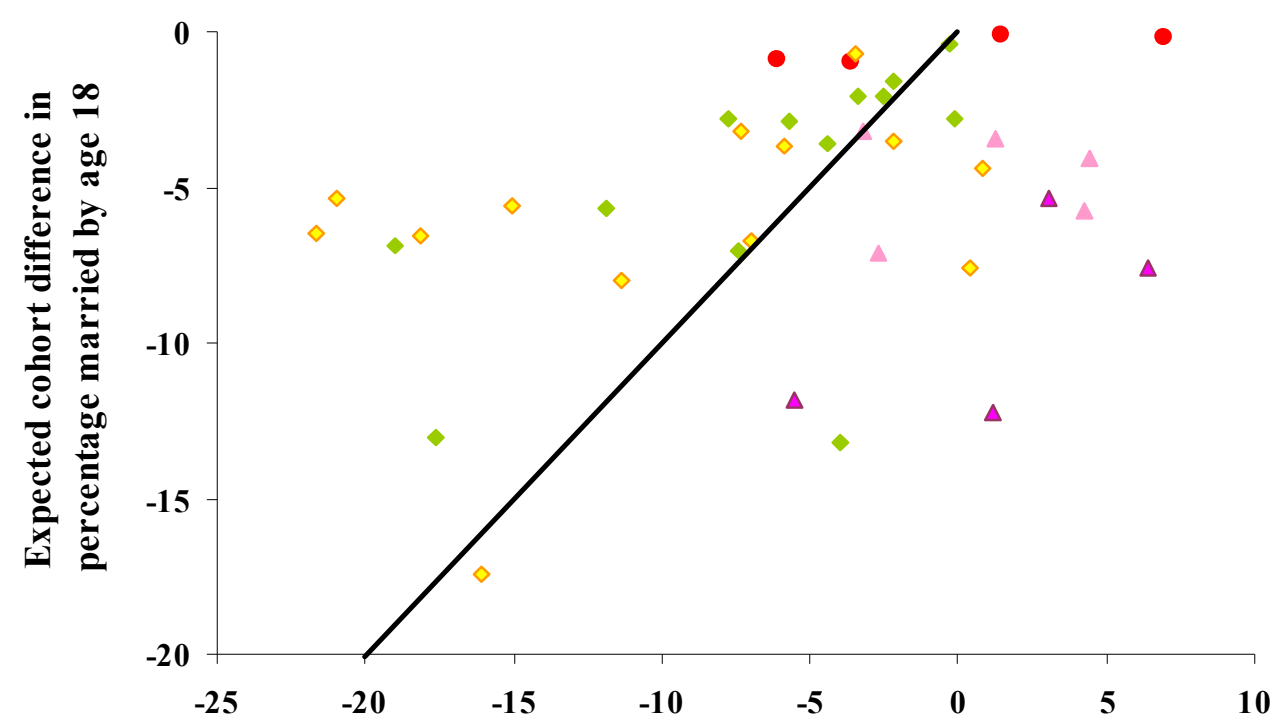

Observed cohort difference in percentage married by age 18

South America

$\triangle$ Caribbean/Central America $\bullet$ Former Soviet Asia

Western/Middle Africa

$\diamond$ Eastern/S outhern Africa

${ }^{a}$ The expected change is the change expected as a result of cohort difference in educational attainment.

Note: The line represents the set of points where the observed equals the expected finding. See text.

Source: DHS tabulations, 39 countries, 1990-2001. See Appendix Table A-1 for list of countries. Middle East, South-central and Southeastern Asia are excluded because surveys for these regions are limited to ever-married samples. Gabon is excluded because data on women were unavailable at time of this analysis. 
Figure 3: Association between change in percentage of 15-19-year-old women married and change in percentage of population living in urban areas, 1960-2001

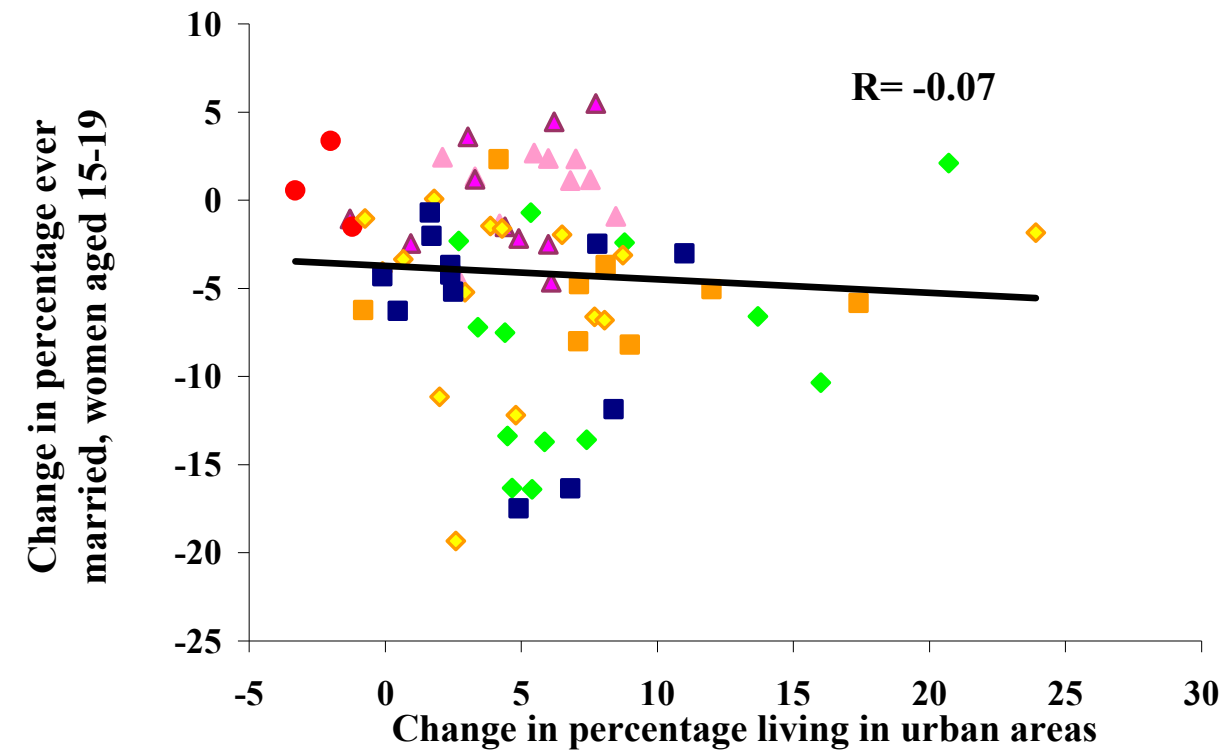

\section{$\triangle$ South America \\ Western/Middle Africa \\ Middle East}

$\triangle$ Caribbean/Central America

$\diamond$ Eastern/Southern Africa
- Former Soviet Asia

- South-central/Southeastern Asia

Source: United Nations, Department of Economic and Social Affairs, Population Division database, 72 countries, 1960-2001. See Appendix Table A-1 for list of countries. Argentina is excluded because no marriage data were available for this age group in first survey period. 
Figure 4: Association between change in percentage of men aged 20-24 and 40-44 married by age 20 and change in grades of school they attained

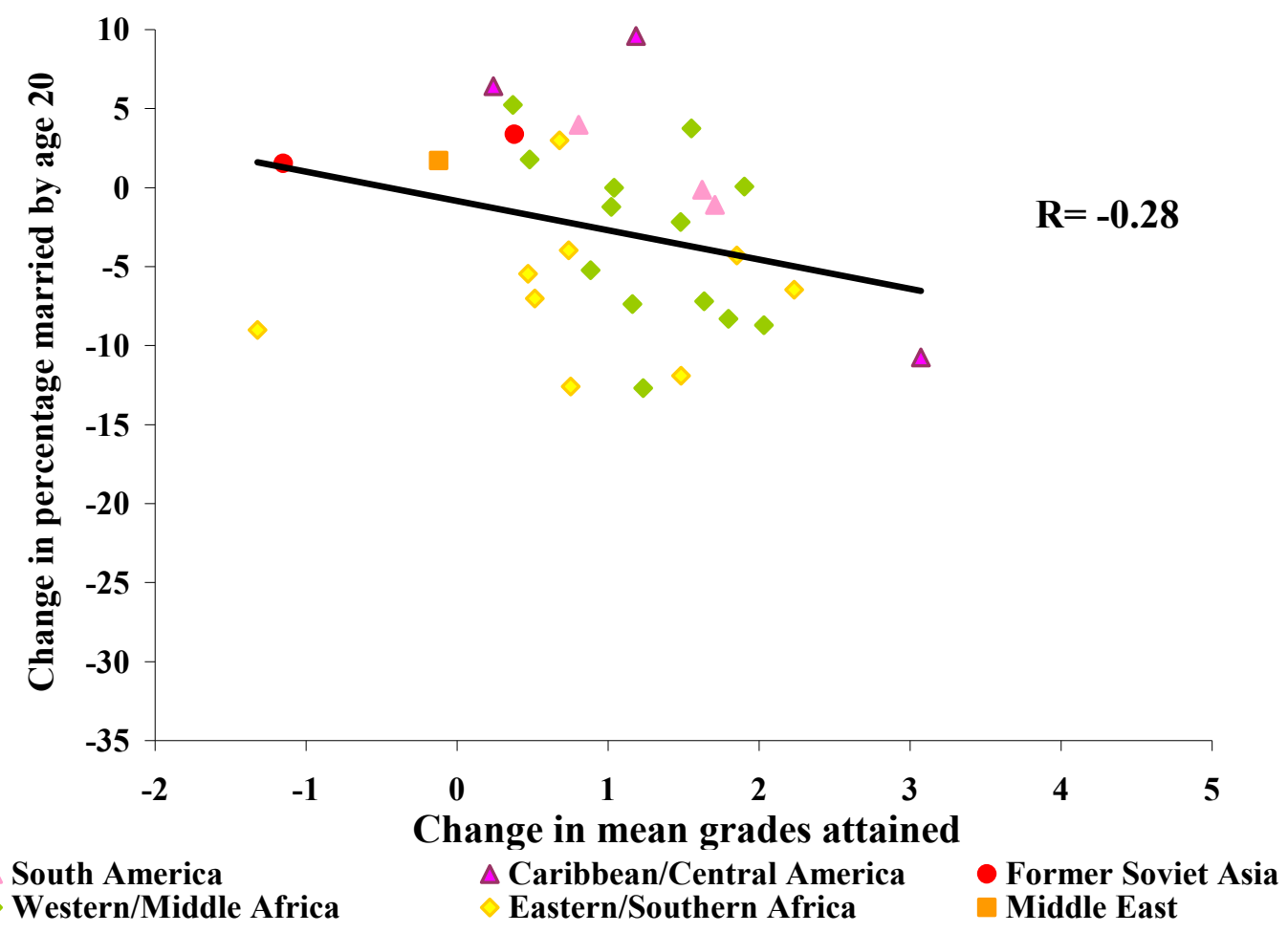

Source: DHS tabulations, 31 countries, 1994-2001. See Appendix Table A-1 for list of countries. Gabon is excluded because data on schooling are missing. 
Figure 5: Association between change in percentage of 20-24-year-old men married and change in percentage of population living in urban areas, 1960-2001

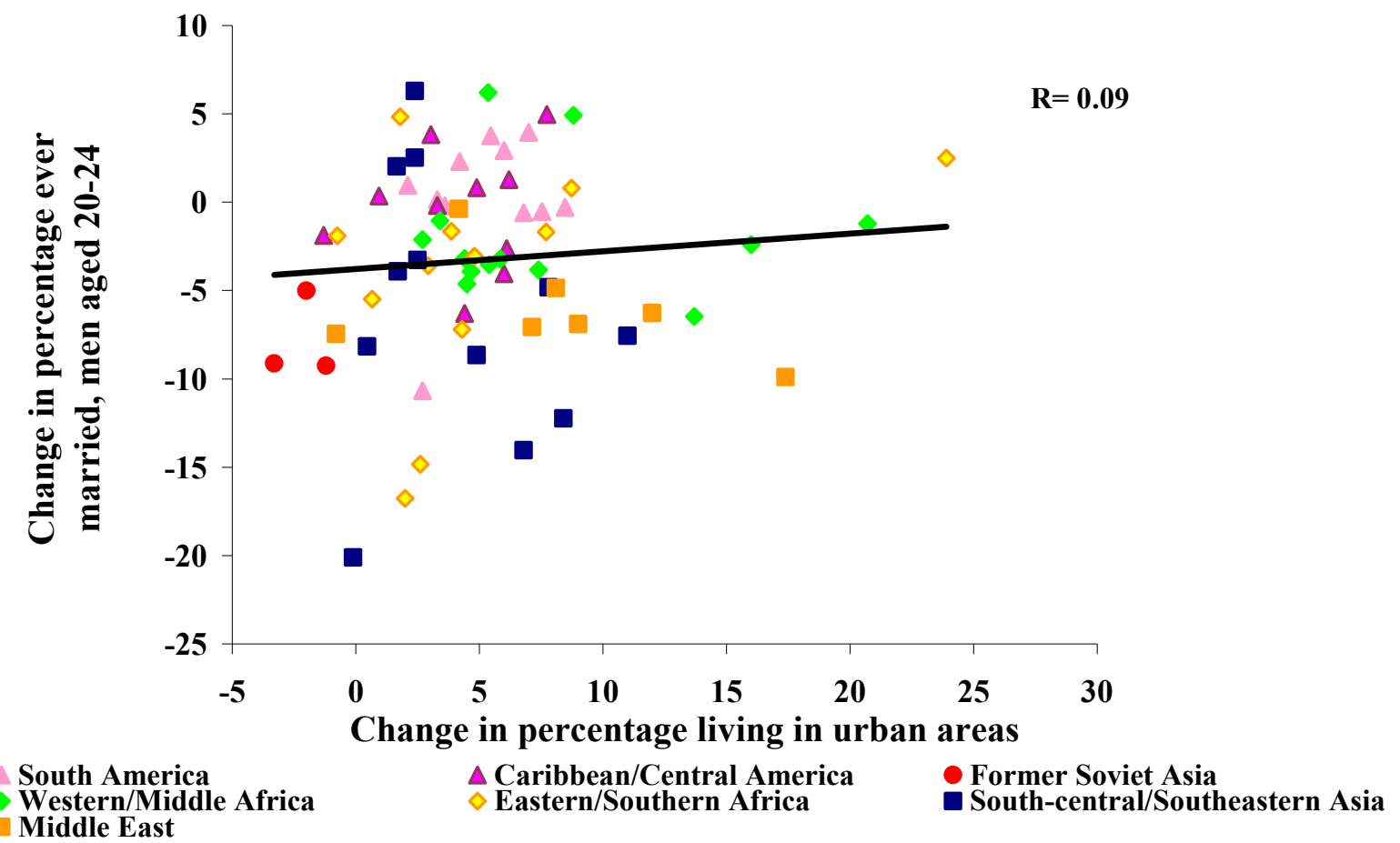

Source: United Nations, Department of Economic and Social Affairs, Population Division database, 72 countries, 1960-2001. See Appendix Table A-1 for list of countries. Bahrain is excluded because survey used nonstandard age grouping. 
Appendix Table A-1: Countries by data source, according to region and survey year

\begin{tabular}{|c|c|c|c|c|c|c|c|}
\hline \multicolumn{4}{|c|}{$\begin{array}{l}\text { United Nations, Department of Economic and Social Affairs, } \\
\text { Population Division database on marriage }\end{array}$} & \multicolumn{4}{|c|}{ Demographic and Health Surveys } \\
\hline Country & Region $^{a}$ & $\begin{array}{l}\text { Census/survey } \\
\text { year } 1\end{array}$ & $\begin{array}{l}\text { Census/survey } \\
\text { year } 2\end{array}$ & Country & Region $^{a}$ & $\begin{array}{l}\text { Most recent } \\
\text { survey }\end{array}$ & $\begin{array}{l}*=\text { Includes } \\
\text { survey of } \\
\text { men }\end{array}$ \\
\hline Belize & Carib/CA & 1980 & 1991 & Dominican Republic & Carib/CA & 1996 & $*$ \\
\hline Dominican Republic & $\mathrm{Carib} / \mathrm{CA}$ & 1981 & 1996 & Guatemala & Carib/CA & 1998-99 & \\
\hline El Salvador & Carib/CA & 1971 & 1992 & Haiti & Carib/CA & 2000 & $*$ \\
\hline Guatemala & Carib/CA & 1973 & 1990 & Nicaragua & Carib/CA & 1997-98 & $*$ \\
\hline Haiti & Carib/CA & 1989 & 2000 & Comoros & E/S Africa & 1996 & $*$ \\
\hline Mexico & Carib/CA & 1980 & 1990 & Ethiopia & E/S Africa & 1999 & $*$ \\
\hline Nicaragua & $\mathrm{Carib} / \mathrm{CA}$ & 1971 & 1998 & Kenya & E/S Africa & 1998 & $*$ \\
\hline Panama & Carib/CA & 1980 & 1990 & Madagascar & E/S Africa & 1997 & \\
\hline Puerto Rico & Carib/CA & 1980 & 1990 & Malawi & E/S Africa & 2000 & $*$ \\
\hline Trinidad and Tobago & Carib/CA & 1980 & 1990 & Mozambique & E/S Africa & 1997 & $*$ \\
\hline Botswana & E/S Africa & 1981 & 1991 & Namibia & E/S Africa & 1992 & \\
\hline Burundi & E/S Africa & 1979 & 1990 & Rwanda & E/S Africa & 2000 & \\
\hline Comoros & E/S Africa & 1980 & 1996 & South Africa & E/S Africa & 1998 & \\
\hline Ethiopia & E/S Africa & 1984 & 2000 & Tanzania & E/S Africa & 1999 & $*$ \\
\hline Kenya & E/S Africa & 1969 & 1998 & Uganda & E/S Africa & $2000-01$ & $*$ \\
\hline Malawi & E/S Africa & 1987 & 2000 & Zambia & E/S Africa & $1996-97$ & $*$ \\
\hline Mauritius & E/S Africa & 1972 & 1990 & Zimbabwe & E/S Africa & 1999 & $*$ \\
\hline Mozambique & E/S Africa & 1980 & 1997 & Egypt & $\mathrm{ME}$ & 2000 & \\
\hline Namibia & E/S Africa & 1960 & 1991 & Jordan & $\mathrm{ME}$ & 1997 & \\
\hline Rwanda & E/S Africa & 1978 & 1996 & Morocco & $\mathrm{ME}$ & 1992 & \\
\hline South Africa & E/S Africa & 1985 & 1996 & Turkey & $\mathrm{ME}$ & 1998 & $* b$ \\
\hline Tanzania & E/S Africa & 1978 & 1996 & Yemen & $\mathrm{ME}$ & 1991-92 & \\
\hline Uganda & E/S Africa & 1969 & 1995 & Bolivia & $\mathrm{SA}$ & 1998 & $*$ \\
\hline Zambia & E/S Africa & 1980 & 1999 & Brazil & $\mathrm{SA}$ & 1996 & $*$ \\
\hline Zimbabwe & E/S Africa & 1982 & 1999 & Colombia & $\mathrm{SA}$ & 2000 & \\
\hline China & EA & 1987 & 1999 & Paraguay & SA & 1990 & \\
\hline
\end{tabular}


Appendix Table A-1: Countries by data source, according to region and survey year (continued)

United Nations, Department of Economic and Social Affairs, Population Division database on marriage

Demographic and Health Surveys

\begin{tabular}{|c|c|c|c|c|c|c|c|}
\hline & & & & & & & \\
\hline Country & Region $^{a}$ & $\begin{array}{l}\text { Census/survey } \\
\text { year } 1\end{array}$ & $\begin{array}{l}\text { Census/survey } \\
\text { year } 2\end{array}$ & Country & Region $^{a}$ & $\begin{array}{l}\text { Most recent } \\
\text { survey }\end{array}$ & $\begin{array}{l}*=\text { Includes } \\
\text { survey of } \\
\text { men }\end{array}$ \\
\hline Bahrain & $\mathrm{ME}$ & 1981 & 1991 & Peru & $\mathrm{SA}$ & 2000 & $*$ \\
\hline Egypt & $\mathrm{ME}$ & 1986 & 1996 & Bangladesh & SC/SE Asia & 1999-00 & \\
\hline Jordan & $\mathrm{ME}$ & 1979 & 1994 & India & SC/SE Asia & 1998-00 & \\
\hline Morocco & $\mathrm{ME}$ & 1982 & 1994 & Indonesia & SC/SE Asia & 1997 & \\
\hline $\begin{array}{l}\text { Occupied Palestinian } \\
\text { Territory }\end{array}$ & $\mathrm{ME}$ & 1967 & 1997 & Nepal & SC/SE Asia & $2000-01$ & \\
\hline Sudan & $\mathrm{ME}$ & 1983 & 1993 & Pakistan & $\mathrm{SC} / \mathrm{SE}$ Asia & 1990-91 & \\
\hline Tunisia & $\mathrm{ME}$ & 1984 & 1994 & Philippines & SC/SE Asia & 1998 & \\
\hline Turkey & $\mathrm{ME}$ & 1980 & 1990 & Vietnam & SC/SE Asia & 1997 & \\
\hline Argentina & $\mathrm{SA}$ & 1980 & 1991 & Armenia & Soviet & 2000 & $* b$ \\
\hline Bolivia & SA & 1988 & 1998 & Kazakhstan & Soviet & 1999 & $* b$ \\
\hline Brazil & SA & 1980 & 1996 & Kyrgyz Republic & Soviet & 1997 & \\
\hline Chile & SA & 1982 & 1992 & Uzbekistan & Soviet & 1996 & \\
\hline Colombia & SA & 1973 & 1993 & Benin & W/M Africa & 1996 & $*$ \\
\hline Ecuador & $\mathrm{SA}$ & 1974 & 1990 & Burkina Faso & W/M Africa & 1998-99 & $*$ \\
\hline Guyana & SA & 1980 & 1991 & Cameroon & W/M Africa & 1998 & $*$ \\
\hline Paraguay & SA & 1982 & 1992 & Central African Republic & W/M Africa & $1994-95$ & $*$ \\
\hline Peru & SA & 1981 & 1996 & Chad & W/M Africa & 1996-97 & $*$ \\
\hline Uruguay & SA & 1985 & 1996 & Cote d'Ivoire & W/M Africa & 1998-99 & $*$ \\
\hline Venezuela & $\mathrm{SA}$ & 1974 & 1990 & Gabon & W/M Africa & 2000 & $*^{c}$ \\
\hline Bangladesh & SC/SE Asia & 1981 & 1991 & Ghana & W/M Africa & 1998-99 & $*$ \\
\hline Cambodia & SC/SE Asia & 1962 & 1998 & Guinea & W/M Africa & 1999 & $*$ \\
\hline India & SC/SE Asia & 1981 & 1992-93 & Mali & W/M Africa & 2001 & $*$ \\
\hline Indonesia & SC/SE Asia & 1980 & 1990 & Niger & W/M Africa & 1998 & $*$ \\
\hline Iran & SC/SE Asia & 1986 & 1996 & Nigeria & W/M Africa & 1999 & $*$ \\
\hline Malaysia & SC/SE Asia & 1980 & 1991 & Senegal & W/M Africa & 1997 & $*$ \\
\hline Maldives & SC/SE Asia & 1985 & 1995 & Togo & W/M Africa & 1998 & $*$ \\
\hline
\end{tabular}


Appendix Table A-1: Countries by data source, according to region and survey year (continued)

United Nations, Department of Economic and Social Affairs,

Population Division database on marriage

\begin{tabular}{llll}
\hline Country & & Census/survey & $\begin{array}{c}\text { Census/s } \\
\text { year 2 }\end{array}$ \\
\hline & & & \\
Myanmar & SC/SE Asia & 1973 & 1991 \\
Nepal & SC/SE Asia & 1981 & 1991 \\
Pakistan & SC/SE Asia & 1981 & 1998 \\
Philippines & SC/SE Asia & 1980 & 1995 \\
Thailand & SC/SE Asia & 1980 & 1990 \\
Azerbaijan & Soviet & 1989 & 1999 \\
Kazakhstan & Soviet & 1989 & 1999 \\
Kyrgyz Republic & Soviet & 1989 & 1999 \\
Benin & W/M Africa & 1979 & 1996 \\
Burkina Faso & W/M Africa & 1985 & 1999 \\
Cameroon & W/M Africa & 1987 & 1998 \\
Cape Verde & W/M Africa & 1980 & 1990 \\
Central African Republic & W/M Africa & 1975 & $1994-95$ \\
Chad & W/M Africa & 1964 & 1996 \\
Cote d'Ivoire & W/M Africa & 1978 & 1994 \\
Gabon & W/M Africa & 1961 & 2000 \\
Gambia & W/M Africa & 1983 & 1993 \\
Mali & W/M Africa & 1976 & $1995-96$ \\
Mauritania & W/M Africa & 1988 & $2000-01$ \\
Niger & W/M Africa & 1988 & 1998 \\
Senegal & W/M Africa & 1978 & 1997 \\
\hline & & &
\end{tabular}

${ }^{a}$ Key: Carib/CA (Caribbean and Central America); E/S Africa (Eastern and Southern Africa); EA (Eastern Asia); ME (Middle East [Northern Africa and Western Asia]); SA (South America); SC/SE Asia (South-central and Southeastern Asia); Soviet (Former Soviet Asia); W/M Africa (Western and Middle Africa).

${ }^{b}$ Survey data for men are available for these countries, but not in sufficient number to allow aggregation of data to generate regional averages.

${ }^{c}$ Gabon data on women were unavailable at the time of this analysis; data on men do not include schooling.

Note: Middle East, South-central, and Southeastern Asia are excluded from Figure 2 and Table 8 because the surveys are based on ever-married samples. 


\section{POLICY RESEARCH DIVISION WORKING PAPERS}

If still in print, single copies of up to three working papers from 1989 through 2003 are available free of charge.

Beginning with the 2004 issues, working papers are no longer available in print format. Instead they are distributed electronically. As each new paper is completed subscribers are notified by e-mail and a link to the paper is provided.

To subscribe to the Policy Research Division working paper e-mail notification list, or to obtain back issues from 1989 to 2003, please send your request to prdwp@popcouncil.org.

PDFs of recent issues are available at www.popcouncil.org/publications/wp/prd/rdwplist.html

2005

202 Barbara S. Mensch, Susheela Singh, and John B. Casterline, "Trends in the timing of first marriage among men and women in the developing world."

201 Zachary Zimmer, “Active life expectancy and functional limitations among older Cambodians: Results from a 2004 survey."

200 Brian Wells Pence, Philomena Nyarko, James F. Phillips, and Cornelius Debpuur, "The effect of community nurses and health volunteers on child mortality: The Navrongo Community Health and Family Planning Project."

199 Zachary Zimmer, Linda G. Martin, Mary Beth Ofstedal, and Yi-Li Chuang, "Education of adult children and mortality of their elderly parents in Taiwan."

198 Mian Bazle Hossain, James F. Phillips, and Thomas K. LeGrand, "The impact of childhood mortality on fertility in six rural thanas of Bangladesh."
197 Kristine R. Baker, Mary Beth Ofstedal, Zachary Zimmer, Zhe Tang, and Yi-Li Chuang, "Reciprocal effects of health and economic well-being among older adults in Taiwan and Beijing."

196 Mark R. Montgomery and Paul C. Hewett, "Poverty and children's schooling in urban and rural Senegal."

2004

195 Luciana Suran, Sajeda Amin, Lopita Huq, and Kobita Chowdury, "Does dowry improve life for brides? A test of the bequest theory of dowry in rural Bangadesh.”

194 Barbara S. Mensch, Monica J. Grant, Mary P. Sebastian, Paul C. Hewett, and Dale Huntington. "The effect of a livelihoods intervention in an urban slum in India: Do vocational counseling and training alter the attitudes and behavior of adolescent girls?" 
193 Amanda Ritchie, Cynthia B. Lloyd, and Monica Grant. "Gender differences in time use among adolescents in developing countries: Implications of rising school enrollment rates."

192 John Bongaarts. "Long-range trends in adult mortality: Models and projection methods."

191 John Koku Awoonor-Williams, Ellie S. Feinglass, Rachel Tobey, Maya N. Vaughan-Smith, Frank K. Nyonator, Tanya C. Jones, and James F. Phillips, "Bridging the gap between evidence-based innovation and national healthsector reform in Ghana."

190 Kelly Hallman, "Socioeconomic disadvantage and unsafe sexual behaviors among young women and men in South Africa."

189 Toshiko Kaneda, Zachary Zimmer, and Zhe Tang, "Differentials in life expectancy and active life expectancy by socioeconomic status among older adults in Beijing."

188 Cynthia B. Lloyd and Monica J. Grant, "Growing up in Pakistan: The separate experiences of males and females."

187 Zachary Zimmer, Xianghua Fang, Toshiko Kaneda, Zhe Tang, and Julia Kwong. "Trends and transitions in children's coresidence with older adults in Beijing municipality."
186 Sajeda Amin and Alaka M. Basu. "Popular perceptions of emerging influences on mortality and longevity in Bangladesh and West Bengal."

185 John Bongaarts. "Population aging and the rising cost of public pensions."

184 Mark R. Montgomery and Paul C. Hewett. "Urban poverty and health in developing countries: Household and neighborhood effects.

2003

183 Agnes R. Quisumbing and Kelly Hallman. "Marriage in transition: Evidence on age, education, and assets from six developing countries."

182 Paul C. Hewett, Barbara S. Mensch, and Annabel S. Erulkar, "Consistency in the reporting of sexual behavior among adolescent girls in Kenya: A comparison of interviewing methods."

181 Zachary Zimmer, Linda G. Martin, and Hui-Sheng Lin, "Determinants of old-age mortality in Taiwan."

180 Frank K. Nyonator, J. Koku Awoonor-Williams, James F. Phillips, Tanya C. Jones, and Robert A. Miller, "The Ghana Community-based Health Planning and Services Initiative: Fostering evidence-based organizational change and development in a resourceconstrained setting." 
179 John Bongaarts and Griffith

Feeney, "Estimating mean

lifetime."

178 Elizabeth F. Jackson, Patricia Akweongo, Evelyn Sakeah, Abraham Hodgson, Rofina Asuru, and James F. Phillips, "Women's denial of having experienced female genital cutting in northern Ghana: Explanatory factors and consequences for analysis of survey data."

177 John Bongaarts, "Completing the fertility transition in the developing world: The role of educational differences and fertility preferences."

176 Cynthia B. Lloyd and Paul C. Hewett, "Primary schooling in sub-Saharan Africa: Recent trends and current challenges."

175 James F. Phillips, Tanya C. Jones, Frank K. Nyonator, and Shruti Ravikumar, "Evidence-based development of health and family planning programs in Bangladesh and Ghana."

174 Geoffrey McNicoll, "Population and development: An introductory view."

173 Paul Demeny, "Population policy: A concise summary."

172 Zachary Zimmer, Napaporn Chayovan, Hui-Sheng Lin, and Josefina Natividad, "How indicators of socioeconomic status relate to physical functioning of older adults in three Asian societies."
171 Sajeda Amin and Nagah H. AlBassusi, "Wage work and marriage: Perspectives of Egyptian working women."

170 Ravai Marindo, Steve Pearson, and John B. Casterline, "Condom use and abstinence among unmarried young people in Zimbabwe: Which strategy, whose agenda?"

169 Zachary Zimmer and Julia Dayton, "The living arrangements of older adults in sub-Saharan Africa in a time of HIV/AIDS."

168 Paul C. Hewett, Annabel S. Erulkar, and Barbara S. Mensch, "The feasibility of computerassisted survey interviewing in Africa: Experience from two rural districts in Kenya." 